\title{
The Court of Justice of the European Union's Mutual Trust Journey in EU Criminal Law: From a Presumption to (Room for) Rebuttal
}

\author{
Auke Willems*
}

(Received 18 December 2017; accepted 10 April 2018)

\begin{abstract}
More than any other EU institution, the Court of Justice of the European Union has upheld the presumption of mutual trust in EU criminal law cooperation. Surprisingly though, despite mutual trust's centrality in the Court's jurisprudence, it has long not qualified nor properly elaborated the notion of trust, but rather held on to its presumed existence based on a high level of fundamental rights protection throughout the Union. This article will assess the important role of the Court in establishing, upholding and ultimately qualifying the trust presumption in the EU criminal justice context. Along the lines of a number of key cases, the narrative of a strong defence of (the presumption of) mutual trust appears, but also of an evolution toward more room for rebuttal in recent cases. This signals the increased weight given to fundamental rights protection in the EU's Area of Freedom, Security and Justice.
\end{abstract}

Keywords: mutual trust; mutual recognition; EU criminal law; fundamental rights; Court of Justice of the European Union

\section{A. Introduction}

The term mutual trust is widely used in the EU criminal justice discourse, for example in policy documents, legislation, and case law. To be more precise, it has become the focal point of the EU's criminal justice policy, ${ }^{1}$ and is "the bedrock upon which EU justice policy should be built." 2 Nevertheless, there is no commonly agreed definition or understanding of its scope and fundamentals in EU circles - in other words, the institutions. ${ }^{3}$ The term was given prominence from the beginning of EU criminal law ${ }^{4}$ cooperation when the 1999 Tampere European Council hailed mutual recognition as the cornerstone principle of criminal justice cooperation. ${ }^{5}$ Mutual

${ }^{\star}$ Auke Willems is a Fellow in EU Law at the London School of Economics. An earlier version of this paper was presented at the Edinburgh Europa Institute (18 October 2016). The author is grateful to Anne Weyembergh, Paul de Hert, and Leandro Mancano for their comments on earlier drafts. Any errors remain solely with the author. This Article covers legal developments up to April 6, 2018.

${ }^{1} 2010$ O.J. (C 115/1) 1.2.1 (identifying in the Stockholm Programme: "[E]nsuring trust and finding new ways increase reliance on, and mutual understanding between, the different systems in the Member States" as "one of the main challenges for the future").

${ }^{2} J$ ustice Agenda for 2020 - Strengthening Trust, Mobility and Growth Within the Union, COM (2014) 144 final; confirmed in the Commission's Work Programme 2017, COM (2016) 710 final.

${ }^{3}$ See also Auke Willems, Mutual Trust as a Term of Art in EU Criminal Law: Revealing its Hybrid Character, 9 EUR. J. LEGAL STUD. 211 (2016).

${ }^{4} \mathrm{~A}$ note at the outset: The term "EU criminal law" is potentially misleading. We are not dealing with conventional criminal law; no norms that pose an immediate threat to individuals are created at EU level. Nevertheless, the term is widely accepted to describe the body of law and policy under examination here.

${ }^{5}$ Eur. Consult. Ass., Tampere European Council Presidency Conclusions, para. 53 (Oct. 15-16, 1999). 
recognition gained further importance with the introduction of the Area of Freedom, Security and Justice ("AFSJ"), the EU's version of a judicial space that came into force through the Treaty of Amsterdam. Additionally, mutual recognition especially gained importance with the adoption of the European Arrest Warrant ("EAW"), ${ }^{6}$ applying mutual recognition to extradition. ${ }^{7}$ In essence, mutual recognition requires Member States to give full recognition to judicial decisions from other jurisdictions across the EU. ${ }^{8}$ The Lisbon Treaty incorporated mutual recognition and has thus become part of primary EU law. ${ }^{9}$

Mutual recognition functions on a presumption of mutual trust. The logic is that the "extraterritoriality of judicial decisions," 10 created by mutual recognition, will only be accepted if there is sufficient mutual trust between Member States. ${ }^{11}$ In other words, mutual trust serves as the foundation of mutual recognition. As noted by Janssens, however, "the precise link between trust and recognition has not been decisively elucidated." 12 Herlin-Karnell adds, "[t]he key problem that arises when discussing the notion of EU criminal law cooperation is that there is no articulation of what 'mutual trust' actually means in the field of criminal law. This lack of conceptualization is a significant lacuna in EU criminal law cooperation."13

In addition to conceptual uncertainty, the feasibility of a presumption of mutual trust was soon questioned, ${ }^{14}$ and it turned out that "[b]lind mutual recognition of foreign decisions is not feasible due to the lack of trust that is caused by the differences in member states' criminal justice systems." 15 An influential study conducted by Vernimmen-van Tiggelen et al. concluded —on the basis of interviews with practitioners working in the field—-that "mutual trust was simply assumed to exist ... [i]n reality, this trust is still not spontaneously felt and is by no means always evident in practice ...." 16

Despite the fact that the pre-Lisbon Court of Justice of the European Union ("CJEU") ${ }^{17}$ had limited jurisdiction on matters relating to criminal law and was subject to a five year transitional period under Lisbon, ${ }^{18}$ it has not hesitated to rule on matters relating to the AFSJ. ${ }^{19}$ More than any

\footnotetext{
${ }^{6}$ Council Framework Decision 2002/584/JHA, 2002 O.J. (L190/1) (EC) [hereafter EAW].

${ }^{7} \mathrm{See}$, e.g., Libor KLIMEK, EUROPEAN ArRest Warrant (2014) (discussing more of the EAW).

${ }^{8}$ See, e.g., Christine Janssens, The Principle of Mutual Recognition in EU LaW (2013) (discussing more on mutual recognition).

${ }^{9}$ Consolidated Versions of the Treaty on European Union and the Treaty on the Functioning of the European Union, arts. 67(3), 82(1), July 6, 2016, 2016 O.J. (C 202) 1. [hereinafter TEU and TFEU respectively].

${ }^{10}$ See Kalypso Nicolaïdis, Trusting the Poles? Constructing Europe Through Mutual Recognition, 14 J. Eur. PUB. POL. 682 (2007).

${ }^{11}$ See, e.g., Thomas Wischmeyer, Generating Trust Through Law? Judicial Cooperation in the European Union and the "Principle of Mutual Trust", 17 German L.J. 339 (2016) (regarding mutual trust in EU criminal law); see generally LA Confiance Mutuelle Dans l’espace Pénal Européen/Mutual trust in the European Criminal Area (Gilles De Kerchove \& Anne Weyembergh eds., 2005).

${ }^{12}$ JANSSENS, supra note 8 , at 142 .

${ }^{13}$ Ester Herlin-Karnell, Constitutional Principles in the Area of Freedom, Security and Justice, in EU SECURITY AND JUSTICE Law After Lisbon and Stockholm 38, at 42 (Diego Acosta Arcarazo \& Cian C. Murphy eds., 2014).

${ }^{14}$ See Susie Alegre and Marisa Leaf, Mutual Recognition in European Judicial Cooperation: A Step Too Far Too Soon?, 10(2) EUR. L.J. 200 (2004).

${ }^{15}$ Gert Vermeulen, Wendy de Bondt \& Peter Verbeke, Correction Mechanisms: A Necessity in the Current Cooperation Climate, in 42 Rethinking International Cooperation in Criminal Matters in the EU 337 (Gert Vermeulen, Wendy de Bondt \& Charlotte Ryckman eds., 2012).

${ }^{16}$ The Future of Mutual Recognition in Criminal Matters in the European Union/L'avenir de La Reconnaissance Mutuelle en Matière Pénale dans l’Union Européenne 20 (Giséle Vernimmen-Van Tiggelen, Laura Surano \& Anne Weyembergh eds., 2009); see also Ulrich Sieber, Die Zukunft des Europäischen Strafrechts, 121 ZeitsChrift GESAMTE STRAFRECHTSWISSENSCHAFT 1, 33-34 (2009) (concluding that mutual trust does not exist).

${ }^{17}$ The post-Lisbon name of the Court is used throughout, being mindful of its pre-Lisbon designation: European Court of Justice ("ECJ") even though this term is still used nowadays.

${ }^{18}$ Accordingly, until December 2014, the pre-Lisbon rules that limited the Court's jurisdiction remained in force. See TFEU protocol no. 36 .

${ }^{19}$ See, e.g., Koen Lenaerts, The Contribution of the European Court of Justice to the Area of Freedom, Security and Justice, 59 INT'L \& COMP. L.Q. 255 (2010); Lars Bay Larsen, Judicial Control Within the European Penal Area, in THE JUDICIAL CONTROL IN EU CoOperation In Criminal MatTers 13 (Stefan Braum \& Anne Weyembergh eds., 2009).
} 
other EU institution, the Court safeguarded the presumption of trust and became one of its strongest defenders. ${ }^{20}$ Despite mutual trust's centrality in the Court's ASFJ jurisprudence, the Court has not qualified or properly elaborated the notion of trust. Rather, the Court held on to its presumed existence based on a high level of fundamental rights protection throughout the EU based on Article 6 of the European Convention on Human Rights ("ECHR"). ${ }^{21}$ Moraru, however, observed that "EU law and [the] jurisprudence of the [CJEU] seem to attach different meanings and effects to 'mutual trust' depending on the specific field of the AFSJ," moreover, " $[t]$ he fact that most of the CJEU case law dealing with issues related to the clarification of the meaning and effects of 'mutual trust' stems from national courts is an indication of the confusion surrounding the EU concept of 'mutual trust'."22

This Article will assess the important role of the CJEU in establishing, upholding, and ultimately qualifying the trust presumption in the EU criminal justice context. The issue is not isolated, but linked with other areas of EU involvement-predominantly EU asylum law-which will be discussed when relevant. ${ }^{23}$ Along the lines of relevant case law, this Article will lay out the narrative of a strong defense for-the presumption of - mutual trust, but also of an evolution toward more room for rebuttal in recent cases. ${ }^{24}$ The Court long resisted urgent calls from academic commentators and practitioners to allow rebuttal of the trust presumption on human rights grounds, ${ }^{25}$ as the negative impact of mutual recognition on fundamental rights ${ }^{26}$ was clearly visible. ${ }^{27}$

By doing so, the Court came to recognize mutual trust as a "normative principle underlying cooperative regulatory instruments." ${ }^{28}$ It is the normative content of the principle that this Article is interested in, and the degree to which its existence is presumed to exist. Therefore, the question this Article aims to answer is: How has the CJEU interpreted the principle of mutual trust?

A majority of the cases in this Article center around the EAW. This cannot be a surprise in light of the significance of the instrument. A further reason for the relatively large amount of litigation on the EAW is attributed by Bay Larsen to the at times questionable legislative quality of the EAW: "[B]y not clearly resolving difficult key questions or sometimes even leaving such questions completely out of the legal text-[the EAW] often delegated legislative power

\footnotetext{
${ }^{20}$ See also Tomasz Ostropolski, The CJEU as a Defender of Mutual Trust, 6 New J. EUR. CRIM. L. 166 (2015).

${ }^{21}$ See, e.g., Sarah Summers, Fair Trials: The European Criminal Procedural Tradition and the European Court of Human Rights (2007).

${ }^{22}$ Madalina Moraru, "Mutual Trust" from the Perspective of National Courts: A Test in Legal Thinking, in MAPPING MUTUAL Trust: Understanding and Framing the Role of Mutual Trust in EU Law, 13 EUI Working Papers 37, 37 (Evelien Brouwer \& Damien Gerard eds., 2016).

${ }^{23}$ See Valsamis Mitsilegas, The Limits of Mutual Trust in Europe's Area of Freedom, Security and Justice: From Automatic Inter-State Cooperation to the Slow Emergence of the Individual, 31 Y.B. EUR. L. 319 (2012) (regarding an ASFJ wide assessment).

${ }^{24}$ See also Ester Herlin-Karnell, From Mutual Trust to the Full Effectiveness of EU Law: 10 Years of the European Arrest Warrant, 38 EUR. L. REV. 79 (2013).

${ }^{25}$ See, e.g., Malcom Anderson, Law Enforcement Cooperation in the EU and Fundamental Rights Protection, in CRIME, Rights and the EU: The Future of Police and Judicial Cooperation 105 (Martin Maik ed., 2008); Kai Ambos, Mutual Recognition Versus Procedural Guarantees?, in Criminal Proceedings in the European Union: Essential SAFEgUARDS 25 (Montserrat de Hoyos Sancho ed., 2008).

${ }^{26}$ See Paul de Hert, EU Criminal Law and Fundamental Rights, in RESEARCH HaNdBook ON EU CRIMINAL LAW 105 (Valsamis Mitsilegas, Maria Bergström \& Theodore Konstadinides eds., 2016) (discussing EU criminal law and fundamental rights generally).

${ }^{27}$ See, e.g., The European Arrest Warrant eight years on — time to amend the Framework Decision?, FAIR TRIALS INTERNATIONAL (Feb. 1, 2012), https://www.fairtrials.org/documents/EAW_EP_own_initiative_legislative_report.pdf (publishing various studies on the negative impact of mutual recognition on fundamental rights).

${ }^{28}$ Damien Gerard, Mutual Trust as Constitutionalism?, in Mapping Mutual Trust: Understanding and Framing The Role of Mutual Trust in EU Law, 13 EUI Working Papers 69, 75 (Evelien Brouwer \& Damien Gerard eds., 2016).
} 
to the ECJ." ${ }^{29}$ One of the major controversies surrounding the EAW is the absence of a fundamental rights refusal ground-intended as the ultimate expression of mutual trust. There has long been debate about how this absence should be interpreted. ${ }^{30}$

Section B will begin with the Court's introduction of the idea of mutual trust in the criminal law context in a series of cases on ne bis in idem. In section C, the first EAW case will be examined. In Advocaten voor de Wereld the Court confirmed the validity of the instrument and laid the foundation for the cases to follow. Subsequent cases following this important judgment dealt with questions about the limits of mutual recognition in relation to nationals, which is discussed in section D. Then, in section E, Mantello is examined, which is the first EAW case directly dealing with fundamental rights. Section F analyzes N.S., the first AFSJ case in which the trust presumption was rebutted. Even though this judgment concerns asylum law, it has proven to be a significant development that would later be exported to the criminal sphere. Nevertheless, the first cases on a possible human rights refusal in the context of the EAW following N.S. did not yet lead to the Court recognizing such possibility, as will be examined in section G. But these cases were not the final word on the issue, and as the concerns surrounding the protection of individual rights in the operation of the EAW grew, the Court ultimately came to move in the direction of limiting mutual recognition when human rights concerns would warrant this. But before it did, the Court once more underlined the importance of the principle of mutual trust and its presumed existence in Opinion 2/13, which is the topic of section H. Ultimately, the Court showed readiness to change its rigid position regarding the trust presumption in Aranyosi and Căldăraru, which will be the focus of section I. The last section, J, will synthesize the different components of a body of jurisprudence that evolved towards accepting that there are limits to mutual trust in the criminal sphere. But despite this recent change of the Court's reading of mutual trust, its role in establishing and defending the trust presumption has beenand remains-paramount.

\section{B. Establishing the Trust Presumption: The EU-Wide Application of Ne Bis in Idem}

The Court's first view of mutual trust came in a ne bis in idem case. The principle of ne bis in idem, or the principle-prohibition - of double jeopardy is contained in various international human rights treaties, ${ }^{31}$ as well as in the EU Charter of Fundamental Rights. ${ }^{32}$ In its most basic form, the principle gives individuals the right to not be prosecuted or tried twice for the same criminal conduct. In that capacity, ne bis in idem concerns a negative application of mutual recognition, namely impeding further prosecution instead of aiding it. ${ }^{33}$ Traditionally, the principle functioned only within a single jurisdiction, thus not barring a second prosecution for the same offense in another state. In the EU context, a transnational variant of the rule applies. ${ }^{34}$ It first emerged in

\footnotetext{
${ }^{29}$ Lars Bay Larsen, Some Reflections on Mutual Recognition in the Area of Freedom, Security and Justice, in Constitutionalising the EU Judicial System: Essays in Honour of Pernilla Lindh 139, 141 (Pascal Cardonnel, Allan Rosas \& Nils Wahl eds., 2012).

${ }^{30}$ See, e.g., Gian Luigi Tosato, Some Remarks on the Limits to the Mutual Recognition of Judicial Decisions in Civil and Criminal Matters Within the European Union, 38 Rivista DI DiRItTo InTERNAZIONALE PRIVATO E PROCESSUALE 869 (2002).

${ }^{31}$ See, e.g., G.A. Res. 2200 (XXI) a, International Covenant on Civil and Political Rights, at 14(7); Protocol No. 7 to the Convention for the Protection of Human Rights and Fundamental Freedoms, Nov. 22, 1984, art. 4; see Auke Willems \& Paul de Hert, Artikel 4 Protocol 7 EVRM, in SDU CommentaAR EVRM DeEl 1: MateriëLE Rechten 1472 (J.H. Gerards, Yves Haeck \& Paul de Hert eds., 2013) (regarding the ECtHR's interpretation of ne bis in idem).

${ }^{32}$ Charter of Fundamental Rights of the European Union art. 50, Dec. 18, 2000, 2000 O.J. (C 364) 1 [hereafter EU Charter].

${ }^{33}$ See also Samuli Miettinen, Criminal Law and Policy in the European Union 181 (2013).

${ }^{34}$ See generally Anne Weyembergh \& Inés Armada, The Principle of ne bis in idem in Europe's Area of Freedom, Security and Justice, in Research HandbooK on EU Criminal LAW 189 (Valsamis Mitsilegas, Maria Bergström \& Theodore Konstadinides eds., 2016).
} 
Article 54 of the Convention Implementing the Schengen Agreement ("CISA") ${ }^{35}$ and aimed to balance any possible negative effects of the abolition of the borders. ${ }^{36}$ In 2003, in Gözütok and Brügge, the Court was asked in a preliminary reference procedure ${ }^{37}$ whether this principle prohibited bringing charges on the same facts in one Member State, which another Member State definitively brought to a close. ${ }^{38}$ The preliminary questions were referred by German and Belgian Courts in cases concerning drugs trade (Gözütok) and causing grievous bodily injury to a person (Brügge). ${ }^{39}$ Both suspects agreed with the Member State's public prosecutor on a financial settlement, upon payment of which further proceedings would be barred. Despite these settlements, new proceedings were initiated against both suspects in another Member State.

In its landmark decision, the Court interpreted Article 54 CISA broadly, ${ }^{40}$ and held that $n e$ bis in idem does bar prosecution on the same facts as those which have been "finally disposed of" in another Member State, even if no court has been involved in the settlement of the criminal proceedings and the settlement does not take the form of a judicial decision. The main justification for such an EU-wide application of ne bis in idem is mutual trust:

[T] here is a necessary implication that the Member States have mutual trust in their criminal justice systems and that each of them recognises the criminal law in force in the other Member States even when the outcome would be different if its own national law were applied. $^{41}$

The judgment came at the beginning of the mutual recognition era, and as observed by Thwaites: "This approach strikingly recalls the reasoning of the Court in the Cassis de Dijon case on mutual recognition regarding the free movement of products" 42 - the policy area, internal market, where the Court first introduced mutual recognition. ${ }^{43}$

Not directly dealing with mutual recognition, though, the Court speaks of recognizing criminal laws of other Member States, even when applying national law would lead to a different outcome, clearly echoing the mutual recognition spirit. The concept that there is a necessary implication of mutual trust established a strong presumption of trust, and the Court presented itself as a guardian of the mutual trust rationale. The Court has since applied the principle of mutual trust in a similar manner in other areas of judicial cooperation, such as civil matters, ${ }^{44}$ family law, ${ }^{45}$ insolvency law, ${ }^{46}$ and asylum law. ${ }^{47}$

\footnotetext{
${ }^{35}$ Council Directive the Schengen as referred to in Article 1(2) of Council Decision 1999/435 2000 O.J. (L 239) 19 (EC).

${ }^{36}$ See Robin Löö, 54 CISA and the Principles of ne bis in idem, 15 EUR. J. CRIME, CRIM. L. \& CRIM. JUST. 309 (2007).

${ }^{37}$ See TFEU art. 267.

${ }^{38}$ Joined Cases C-187/01 \& C-385/01, Gözütok and Brügge, 2003 E.C.R. I-1345.

${ }^{39}$ See John Vervaele, Case Note on Gözütok and Brügge, 41 Common MKT. L. REv. 795 (2004) (discussing the case); Maria Fletcher, Some Developments to the Ne Bis in Idem Principle in the European Union: Criminal Proceedings Against Huseyn Gozutok and Klaus Brugge, 66 MoD. L. REv. 769 (2003).

${ }^{40}$ See André Klip, Grensoverschrijdende Bescherming na Voldoen Transactie?, 2 SEW 92 (2004) (criticizing the broad interpretation).

${ }^{41}$ Gözütok and Brügge, Joined Cases C-187/01 \& C-385/01 at para. 33; see also Opinion of Advocate General Ruiz-Jarabo Colomer at para. 124, Joined Cases C-187/01 and C-385/01, Gözütok and Brügge (Sept. 19, 2002), http://curia.europa.eu/juris/ recherche.jsf?language $=$ en .

${ }^{42}$ Nadine Thwaites, Mutual Trust in Criminal Matters: the European Court of Justice Gives a First Interpretation of a Provision of the Convention Implementing the Schengen Agreement, 4 GERMAN L.J. 253, 260 (2003).

${ }^{43}$ See Sandra Lavenex, Mutual Recognition and the Monopoly of Force: Limits of the Single Market Analogy, 14 J. EUR. PUB. Pol. 762 (2007) (regarding the flaws of this analogy).

${ }^{44}$ See, e.g., Case C-116/02, Gasser v. MISAT, 2003 E.C.R. I-14693; Case C-159/02, Turner v. Grovit, 2004 E.C.R. I03565, paras. 24-28.

${ }^{45}$ See, e.g., Case C-195/08 PPU, Rinau, 2008, E.C.R. I-05271, para. 50; Case C-491/10 PPU, Aguirre Zarraga v. Pelz, 2010 E.C.R. I-14247, paras. $46,70$.

${ }^{46}$ See, e.g., Case C-533/08, TNT Express Nederland v. AXA Versicherung AG, 2010 E.C.R. I-04107, paras. 54-56.

${ }^{47} \mathrm{See}$ section $\mathrm{F}$ of this article below.
} 
In a string of cases on double jeopardy, the Court developed other aspects of ne bis in idem. ${ }^{48}$ These cases all have in common that they contain reference to mutual trust and confirm the necessary implication the court formulated first in Gözütok and Brügge. ${ }^{49}$

Noteworthy is Spasic, ${ }^{50}$ in which the Court confirmed the compatibility of Article 50 Charteralso on double jeopardy - with Article $54 \mathrm{CISA},{ }^{51}$ but forgot to make reference to mutual trust in its decision. As aptly worded by Wasmeier: "One could almost gain the impression that the Court meant to abandon its previous line, perhaps because it had 'lost its faith' in mutual recognition and mutual trust, which so far have played such an eminent role." ${ }^{25}$ There was little time to speculate further about the Court abandoning mutual trust in Spasic,${ }^{53}$ however. A couple of days later it handed down M., ${ }^{54}$ reaffirming the former line started with Gözütok and Brügge. In M., the rationale underlying the judgment was once again that a decision in another Member State precludes further prosecution, ${ }^{55}$ but the Court did not only require deference to final judgments, but also deference to decisions by authorities not to proceed with a case to trial-so called non-lieu decisions. Therefore, $M$. further expands the required trust in foreign legal systems.

Overall, the CJEU broadly interpreted the transnational ne bis in idem rule and allowed very few limitations. ${ }^{56}$ It justified its interpretation of ne bis in idem because of the presumed existence of mutual trust. This is a strong expression of the normative content of trust-based cooperation: Despite diversity, all EU Member States are presumed to guarantee a sufficiently high standard of justice, similar to the equivalence presumption in the internal market context.

\section{The Validity of the European Arrest Warrant: Mutual Trust and Advocaten Voor de Wereld}

Shortly after the Court established the trust presumption in Gözütok and Brügge, it applied the presumption within the EAW context. In Advocaten voor de Wereld, ${ }^{57}$ the first EAW case that reached Luxembourg, the question of the validity of the instrument was raised. ${ }^{58}$ The interest group Advocaten voor de Wereld sought annulment of the Belgian Law transposing the provisions of the EAW into national law before Belgium's Constitutional Court.

The most anticipated question referred to Luxembourg was whether Article 2(2) EAW, abolishing dual criminality for 32 offenses, ${ }^{59}$ breached the principle of legality. In summary, the Court

\footnotetext{
${ }^{48}$ Case C-436/04,Van Esbroeck, 2006 E.C.R. I-02333 (specifying the temporal scope of CISA); Case C-150/05, Van Straaten v. Staat der Nederlanden, 2006 E.C.R. I-09327 (defining the meaning of idem); Case C-467/04, Gasparini, 2006 E.C.R. I-09199 (dealing with time-barred prosecution); Case C-297/07, Bourquain, 2008 E.C.R. I09425 (dealing with sentences that cannot be directly enforced).

${ }^{49}$ See Van Esbroeck, Case C-436/04 at para. 30;Van Straaten, Case C-150/05 at para. 43; Gasparini, Case C-467/04 at para. 30; Bourquain, Case C-297/07 at para. 37.

${ }^{50}$ Case C-129/14 PPU, Spasic, (May 27, 2014).

${ }^{51}$ See John Vervaele, Schengen and Charter-Related Ne Bis in Idem Protection in the Area of Freedom, Security and Justice: M and Zoran Spasic, 52 Common MKT. L. Rev. 1339 (2015).

${ }^{52}$ Martin Wasmeier, Ne Bis In Idem and the Enforcement Condition. Balancing Freedom, Security and Justice?, 5 NEW J. EUR. CRIM. L. 534, 549 (2014).

${ }^{53} I d$. at 549-50 (acknowledging that "[h] $[\mathrm{h}$ owever, this does not seem to be the case: just some days after Spasic, the Court has confirmed and reinforced the approach taken in Gözütok/Brügge").

${ }^{54}$ Case C-398/12, M., para. 41 (June 5, 2014).

${ }^{55} \mathrm{Id}$. at paras. $31-36$.

${ }^{56}$ Case C-469/03, Miraglia, 2005 E.C.R. I-02009 (denying not only the transnational legal effect of a decision, in this case it concerned a decision by a prosecutor not to proceed with charges because charges were brought in court in another Member State, without determination of the merits).

${ }^{57}$ Case C-303/05, Advocaten voor de Wereld v. Leden van de Ministerraad, 2007 E.C.R. I-03633.

${ }^{58}$ See also Florian Geyer, Case Note: Advocaten voor de Wereld, 4 Eur. Const. L. REv. 149 (2008); Dorota Leczykiewicz, Constitutional Conflicts and the Third Pillar, 33 Eur. L. Rev. 230 (2008).

${ }^{59}$ According to the dual criminality requirement, the allegedly criminal conduct underlying the extradition request must be criminalized in both requesting and requested jurisdictions. See, e.g., Nils JAREborg, Double Criminality: STUdies IN INTERNATIONAL CRIMINAL LAW(1989).
} 
did not find a breach of the principle of legality and upheld the measure. ${ }^{60}$ The Council justified its choice regarding the 32 offenses "on the basis of the principle of mutual recognition and in the light of the high degree of trust and solidarity between the Member States." ${ }^{\prime}$ The Court employed a teleological interpretation by underlining the importance of effectiveness in the mutual recognition scheme, with a purpose of introducing a speedy and simplified mechanism for cooperation. In accordance with the nature of mutual recognition, the Court held that the definition of the offenses is a matter of the law of the issuing Member State, which in turn can be presumed to sufficiently safeguard fundamental rights-including the principle of legality. ${ }^{62}$ In other words, presumed trust should mask any differences-plugging the gaps.

As to the purpose of the EAW, the Court, by making reference to Articles 1(1) and 1(2) and recitals 5 and 7 , held that this is:

to replace the multilateral system of extradition between Member States with a system of surrender, ${ }^{63}$ as between judicial authorities, of convicted persons or suspects for the purpose of enforcing judgments or of criminal proceedings based on the principle of mutual recognition. ${ }^{64}$

This turned out to be a logic that the Court came to repeat frequently in its subsequent caselaw on the EAW. Overall, in Advocaten voor de Wereld, the Court gave a clear indication of the path to follow regarding the EAW - and criminal law more generally-endorsing mutual recognition cooperation with a strong emphasis on presumed mutual trust.

\section{A Hidden Nationality Exception? A Question of 'How Much' Trust: Kozlowski, Wolzenburg, and Lopez de Silva Jorge}

One of the novelties of the EAW was doing away with the nationality exception to extradition-a prominent rule in extradition law ${ }^{65}$ — safeguarded in the constitutions of several Member States. ${ }^{66}$ The significance of this move is illustrated by the resistance it caused at the national level, in particular by the various challenges raised at national constitutional courts. ${ }^{67}$ Similar to the partial abolition of dual criminality, this is an expression of mutual trust: Even nationals can be safely extradited within the EU.

There is, however, still some room in the instrument to favor nationals, as well as residents or persons staying in the executing Member State. Article 4(6) of the EAW optionally allows refusal of a request for surrender of the abovementioned category "if the European arrest warrant has been issued for the purposes of execution of a custodial sentence or detention order ... and that State undertakes to execute the sentence or detention order in accordance with its domestic law."

\footnotetext{
${ }^{60}$ Advocaten voor de Wereld, Case C-303/05 at paras. $48-61$.

${ }^{61} I d$. at para. 57.

${ }^{62}$ Ester Herlin-Karnell, In the Wake of Pupino: Advocaten voor de Wereld and Dell'Orto, 8 German L.J. 1147, 1154 (2007) (criticizing this approach: While "such reasoning could be said to be in line with the traditional definition of 'mutual recognition' . . the problem is that this does not in any way remedy the lack of maximum certainty in criminal law").

${ }^{63}$ Surrender is the term used for extradition in the EAW, underlining the ambition of the EAW to replace or revolutionize the traditional extradition procedure. See Michael Plachta, European Arrest Warrant: Revolution in Extradition?, 11 EUR. J. CRIme, CRim. L. \& CRim. Just. 178 (2003).

${ }^{64}$ Advocaten voor de Wereld, Case C-303/05 at para. 28.

${ }^{65}$ See Zsuzsanna Deen-Racsmány \& Rob Blextoon, The Decline of the Nationality Exception in European Extradition?, 13 Eur. J. CRIME, CRIM. L. \& CRIM. JUST. 317 (2005).

${ }^{66}$ See, e.g., GRUNDGESETZ [GG] [BASIC LAw] art. 16(2), translation at http://www.gesetze-im-internet.de/englisch_gg/index.html.

${ }^{67}$ Shortly after the EAW entered into force, constitutional challenges, mainly relating to the surrender of nationals, occurred in Poland, Germany, Greece, Cyprus, and the Czech Republic. See Jan Komárek, European Constitutionalism and the European Arrest Warrant: In Search of the Limits of “Contrapunctual Principles", 44 Common MKT. L. REV. 9 (2007); Zsuzsanna Deen-Racsmány, The European Arrest Warrant and the Surrender of Nationals Revisited: The Lessons of Constitutional Challenges, 14 Eur. J. CRIME, CRIM. L. \& CRIM. JUST. 271 (2006).
} 
A particular issue in light of this provision is favoring nationals over residents or other persons staying in that state. The definition of 'staying in', 'a national', or 'a resident' was surrounded by controversy and interpreted differently by various Member States. ${ }^{68}$ Accordingly, a number of cases on the issue appeared before the Court.

\section{Kozlowski: A Question, but No Answer-Yet}

Kozlowski raised the first preliminary questions on the issues raised, ${ }^{69}$ which centered on the limits of mutual recognition in light of protecting nationals. Kozlowski was a Polish national serving a prison sentence in Germany for unrelated crimes when an EAW was issued to serve a five-month prison sentence in Poland. The German court subsequently asked questions as to the scope of the terms 'resident' and 'staying', and whether they could refuse surrender and execute the sentence in accordance with its own law, which allows refusal of surrender of a foreign national who holds 'habitual residence'. ${ }^{70}$

The Court first "recalls the objective of the [EAW]," namely replacing traditional extradition with a surrender procedure on the basis of mutual recognition. ${ }^{71}$ In answering the question as to the scope of the terms 'resident' and 'staying', the Court makes three important points: ${ }^{72}$ First, the terms 'resident' and 'staying', as in the EAW, "must be defined uniformly, because they concern autonomous concepts of Union law"; ${ }^{73}$ second, the refusal ground of Article 4(6) is included in particular to improve the reintegration chances of the requested person; ${ }^{74}$ and third, in order to determine whether there are sufficient connections between the requested person and the executing Member State in an individual case, the Court makes an "overall assessment of various objective factors." 75 In accordance, the Court requires that a requested person is a 'resident' of the executing Member State, meaning that the person established an actual place of residence there, is 'staying' there, and when - following a stable period of presence in that state - the person acquired connections with that state similar to those resulting from residence. ${ }^{76}$ On this occasion, however, the Court did not have to go into this issue, as Kozlowski was not covered by Article 4(6) EAW. ${ }^{77}$

\section{Wolzenburg: The Same Question, but This Time an Answer}

It was not long, though, before the residency question reappeared. Wolzenburg concerned the Dutch law implementing Article 4(6) EAW. ${ }^{78}$ Wolzenburg, a German citizen, worked and lived with his wife in the Netherlands for over a year when German authorities issued an EAW for purposes of executing a sentence. The Dutch law implementing the EAW provided a mandatory refusal ground for the execution of sentences imposed on Dutch nationals. ${ }^{79}$ A similar mandatory

\footnotetext{
${ }^{68}$ See Wouter van Ballegooij and Radka Koch-Hartmanova, Rechtbank Amsterdam LJN AT 9954 en LJN AU 2813, 54 SociaAl ECONOMISCHE WETGEVING 294 (2006) (regarding the implementation of the provision in the Netherlands).

${ }^{69}$ Case C-66/08, Kozłowski, 2008 E.C.R. I-06041; see Massimo Fichera, Proceedings concerning Szymon Kozłowski, 46 Common MKt. L. Rev 241 (2009) (providing a case note).

${ }^{70}$ Kozłowski, Case C-66/08 at paras. 27-28.

${ }^{71} I d$. at para. 31 (referring to Advocaten voor de Wereld, Case C-303/05 at para. 28).

${ }^{72} \mathrm{See}$ Mitsilegas, supra note 23 , at 339.

${ }^{73}$ Kozłowski, Case C-66/08 at para. 43.

${ }^{74} \mathrm{Id}$. at para. 45.

${ }^{75} \mathrm{Id}$. at paras. $48-49$.

${ }^{76} I d$. at para. 46.

${ }^{77} I d$. at paras. 55-56; View of Advocate General Bot at paras. 40-112, Case C66/08, Kozłowski (Apr. 28. 2008), http://curia. europa.eu/juris/recherche.jsf?language=en (providing a more detailed analysis of the issue).

${ }^{78}$ Case C-123/08, Wolzenburg, 2009, E.C.R. I-09621; see Christine Janssens, Dominic Wolzenburg, 47 COMMON MKT. L. REv 831 (2010) (providing a case note).

${ }^{79}$ Wolzenburg, Case C-123/08 at para. 20; Overleveringswet Apr. 29, 2004, Art. 6(2) ("The surrender of a Netherlands national shall not be permitted if that surrender is sought for the purposes of execution of a custodial sentence imposed on him by final judicial decision.").
} 
refusal ground applies to foreign, non-Dutch, nationals in possession of a residence permit of indefinite duration. ${ }^{80}$ Wolzenburg did not possess a residence permit, as he had not resided in the Netherlands for a continuous period of five years. ${ }^{81}$

The district court of Amsterdam questioned whether the requirement of an indefinite residence permit was compatible with Article 4(6) EAW, whether the unequal treatment of nationals of other Member States in the Dutch law violates the non-discrimination principle of Article 18 of the TFEU, and referred to Luxembourg.

In addressing these issues, the Court first made a number of observations, based on earlier cases, citing Kozlowski, ${ }^{82}$ and indirectly Advocaten voor de Wereld, ${ }^{83}$ to reiterate the general purpose of the EAW-namely surrender governed by mutual recognition. ${ }^{84}$ The Court furthermore made reference to Leymann, in which it held that Member States "are in principle obliged to act upon a European arrest warrant. They must or may refuse to execute a warrant only in the cases listed in Articles 3 and 4." ${ }^{\prime 5}$ The Court held that a limited interpretation of the refusal grounds available "merely reinforces the system of surrender introduced by that Framework Decision to the advantage of an area of freedom, security and justice." ${ }^{86}$ Before the Court examined whether the Dutch implementation legislation was compatible with the EAW, it underlined that "Member States have, of necessity, a certain margin of discretion." ${ }^{\prime 7}$ The Court stressed that while the objective of Article 4(6) is to enable reintegration, it "cannot prevent the Member States, when implementing that Framework Decision, from limiting, in a manner consistent with the essential rule stated in Article 1(2) thereof, the situations in which it is possible to refuse to surrender a person who falls within the scope of Article 4(6) thereof." 88 The Court allowed the Dutch deviation from the reintegration objective, ${ }^{89}$ and thus the exclusion of EU nationals from the protection of Article 4(6), justified by the abuse argument raised by the Dutch government. That argument builds on the fear that a "high degree of inventiveness in the arguments put forward in order to prove that they have a connection to Netherlands society" 90 would otherwise render the system unworkable. The Court found that it is perfectly in line with a reintegration rationale to "pursue such an objective only in respect of persons who have demonstrated a certain degree of integration in the society of that Member State." ${ }^{\text {"1 }}$ When applying this logic to specific categories in Dutch law, the Court upheld the law and found that it did not violate the principle of non-discrimination, justified by the requirement of sufficient integration in the Member State of execution. ${ }^{92}$ Allowing Member States a margin of appreciation in implementing Article 4(6) somewhat contradicts Kozlowski's holding that the terms 'resident' and 'staying' are autonomous concepts of EU law.

\section{Lopes da Silva Jorge: Setting out the Limits}

The last case that requires mention in this section is Lopes da Silva Jorge. ${ }^{93}$ Lopes da Silva was convicted for drug trafficking and sentenced in 2003 to five years in prison. In 2006,

\footnotetext{
${ }^{80}$ Wolzenburg, Case C-123/08 at para. 21; Overleveringswet Apr. 29, 2004, Art. 6(5) ("Paragraphs 1 to 4 shall also apply to a foreign national in possession of a residence permit of indefinite duration in so far as he may be prosecuted in the Netherlands for the offences on which the European arrest warrant is based and in so far as he can be expected not to forfeit his right of residence in the Netherlands as a result of any sentence or measure which may be imposed on him after surrender.").

${ }^{81}$ Wolzenburg, Case C-123/08 at para. 25.

${ }^{82}$ Kozłowski, Case C-66/08 at para. 31.

${ }^{83}$ Advocaten voor de Wereld, Case C-303/05 at para. 28.

${ }^{84}$ Wolzenburg, Case C-123/08 at para. 56.

${ }^{85} \mathrm{Id}$. at para. 57; Case C-388/08 PPU, Leymannn, 2008 E.C.R. I-08993, para. 51.

${ }^{86}$ Wolzenburg, Case C-123/08 at para. 58.

${ }^{87} I d$. at para. 61 .

${ }^{88} I d$. at para. 62.

${ }^{89}$ Kozłowski, Case C-66/08 at para. 45.

${ }^{90}$ Wolzenburg, Case C-123/08 at para. 65.

${ }^{91} I d$. at para. 67.

${ }^{92} \mathrm{Id}$. at para. 68.

${ }^{93}$ Case C-42/11, Lopes Da Silva Jorge, (Sept. 5, 2012).
} 
Portuguese authorities issued an EAW for the execution of that sentence. In the meantime, Lopes da Silva moved to France, where he was employed and married to a French national. He therefore requested to execute his sentence in France and stated that extradition to Portugal "would disproportionately undermine his right to respect for private and family life." 94 But the French law implementing Article 4(6) EAW only allowed for refusal of surrender requests concerning French nationals. ${ }^{95}$ The court of appeal handling the request questioned whether the principle of non-discrimination in Article 18 of the TFEU precludes the French implementation law and referred the question to Luxembourg. ${ }^{96}$

The Court first reiterated its finding in Wolzenburg that Article 4(6) allows Member States to limit the execution of a request for surrender in accordance with the scope set out by the provision. ${ }^{97}$ But as the aim of Article 4(6) is reintegration, "nationals of the Member State of execution and the nationals of other Member States staying or resident in the Member State of execution and who are integrated into the society of that State should not, as a rule, be treated differently." French government argued that it could not execute sentences of non-French EU citizens so long as the Framework Decision on custodial sentences ${ }^{99}$ had not entered into force. ${ }^{100}$ The Court dismissed this argument. ${ }^{101}$ By making reference to Pupino, the Court restated the "obligation to interpret national law in conformity [with framework decisions]." 102 In this particular case, that means non-French EU citizens with sufficiently established ties to France should be covered by the reintegration rationale of Article 4(6). ${ }^{103}$

\section{Some Leeway to Member States, but Within the Bounds of Mutual Trust}

The cases Kozlowski, Wolzenburg, and Lopes da Silva Jorge are examples of the wide divergence in implementation of the EAW. ${ }^{104}$ The Court in all three cases underlined the EAW's mutual trust rationale, only to be refused on the grounds listed therein. Article 4(6) is an example of such a refusal ground, and the Court in Wolzenburg allowed a margin of appreciation in defining the categories of persons it protects. The Dutch law requiring specific conditions for nationals of other EU Member States fell within the margin; the French law drawing a line between nationals and non-nationals did not. Relevant in this connection is that the Citizens' Rights Directive lays out several harmonized standards, and imprisonment in another state has the same effect as expulsion. ${ }^{105}$ The Dutch threshold of five years equates to the Directive's requirement for permanent residence, and the Court's approval should be seen in light of that standard. ${ }^{106}$

Permitting Member States a margin of appreciation in implementing this refusal ground has implications for mutual trust, and may lead to differentiated protection between nationals and non-national residents. ${ }^{107}$ As concluded by Mitsilegas, Wolzburg leaves a rather "contradictory

\footnotetext{
${ }^{94} I d$. at para. 24.

${ }^{95} I d$. at para. 16 .

${ }^{96} I d$. at para. 26.

${ }^{97} I d$. at para. 34; Wolzenburg, Case C-123/08 at paras. 62, 74.

${ }^{98}$ Lopes Da Silva Jorge, Case C-42/11 at para. 40.

${ }^{99}$ Council Framework Decision 2008/909/JHA, 2008 O.J. (L327/27) (EU).

${ }^{100}$ Lopes Da Silva Jorge, Case C-42/11 at para. 45; France instead applied the 1983 Council of Europe Convention on the Transfer of Sentenced Persons, which only applies to nationals.

${ }^{101}$ Lopes Da Silva Jorge, Case C-42/11 at para. 49.

${ }^{102} I d$. at para. 53.

${ }^{103} I d$. at para. 59.

${ }^{104} \mathrm{An}$ important reason for the EAW's difficulties in practice is the incorrect transposition of the Framework Decision into national law; see, e.g., Massimo Fichera, The Implementation of the European Arrest Warrant in the European Union: LaW, Policy and Practice (2011).

${ }^{105}$ Directive 2004/38/EC, 2004 O.J. (L158/77).

${ }^{106} I d$., arts. 16, 28 \& 33(1); see also Ester Herlin-Karnell, European Arrest Warrant Cases and the Principles of Non-discrimination and EU Citizenship, 73 MoD. L. Rev. 824 (2010).

${ }^{107}$ See also Mitsilegas, supra note 23 , at 344.
} 
message with regard to the operation of the system of mutual recognition in criminal matters and the place of mutual trust therein," ${ }^{108}$ particularly when trying to reconcile with earlier judgments on the topic. Wolzburg underlies that some Member States have not yet been willing to equally trust extradition in relation to nationals and non-nationals.

The EAW aimed to abolish the nationality exception to extradition, as that rule reinforced not only links between a state and its citizens, but also the notion that a foreign legal system is different or substandard. This aim is not fully achieved, and Article 4(6) is a reminder. Member States sought some form of exception to extradition related to residency or nationality, and it turns out that the reintegration purposes aim in particular at their own nationals, illustrated by the French and Dutch implementation legislation. These cases signal that limits to mutual recognition are needed in order to keep the system afloat. The Court permitted Member States some leeway; however, this cannot violate the principle of non-discrimination, and should be based on objective factors-the boundaries of which were pointed out in Lopes da Silva.

\section{E. The Relation Mutual Recognition-Mutual Trust Under Examination in Mantello}

The first major fundamental rights test case for the EAW was Mantello. ${ }^{109}$ The Court interpreted the mandatory ne bis in idem refusal ground of Article 3(2) EAW. ${ }^{110}$ Italian authorities issued an EAW for the arrest and surrender of Mantello, an Italian citizen residing in Germany, for purposes of execution of a 2005 sentence for drug trafficking. At the time, no charges were brought for his alleged membership in a criminal organization. But in 2008, an EAW was issued for those offenses, and German authorities arrested him in Stuttgart. The question arose soon after whether Mantello's previous conviction in 2005 precluded Germany from executing the EAW. The German Court reasoned that when Mantello was prosecuted for the drug offences in 2005, Italian authorities must have had sufficient evidence to charge and prosecute him for membership in a criminal organization, but did not do so for tactical reasons because it would impede ongoing investigations. Did this violate ne bis in idem, in particular the idem component, and thus invoke the mandatory refusal ground? The German Court grappled with this issue and referred to Luxembourg.

The Court was effectively asked about the correct interpretation of idem-what constitutes the same acts - and whether the court should answer in accordance with the autonomous EU meaning attributed to the ne bis in idem provision of Article 54 CISA, or in accordance with national law - and in that case the law of the issuing or executing state? These questions touch upon the core of the EAW and mutual recognition more widely and essentially inquire whether an executing state can assess fundamental rights compliance in the issuing state. ${ }^{111}$

First, "the Court came to the fairly unsurprising conclusion that its standing case law on ne bis in idem should be also applied in the context of the EAW."112 But instead of examining whether the acts Mantello was convicted for in 2005 were the same acts as those underlying the EAW, the Court centered its analysis around the element of finally judged-the bis component. The Court examined whether the decision by Italian authorities not to charge Mantello in 2005 with the crime of being a member of a criminal organization was irrevocable. ${ }^{113}$ By reframing the question

\footnotetext{
${ }^{108}$ Mitsilegas, supra note 23, at 342.

${ }^{109}$ Case C-261/09, Mantello, 2010 E.C.R. I-11477; see Jannemieke Ouwerkerk, Mantello, 48 CommON MKT. L. REV. 1687 (2011) (providing a case note); Anne Weyembergh, Arrêts I.B. et Mantello: Le Mandate D'arrêt Européen, 177 J. DroIT EUROPÉEN 71 (2011).

${ }^{110}$ EAW art. 3(2) ("The judicial authority of the Member State of execution ... shall refuse to execute the European arrest warrant ... if the executing judicial authority is informed that the requested person has been finally judged by a Member State in respect of the same acts provided that, where there has been sentence, the sentence has been served or is currently being served or may no longer be executed under the law of the sentencing Member State.").

${ }^{111}$ See also Mitsilegas supra note 23, at 345.

${ }^{112}$ Katalin Ligeti, Judicial Control in the System of Mutual Recognition - the ECJ's Judgment in Mantello, 93 KRITISCHE VIERTELJAHRESSCHRIFT FÜR GESETZGEBUNG UND RECHTSWISSENSCHAFT 380, 381 (2010).

${ }^{113}$ Mantello, Case C-261/09 at paras. $42-44$.
} 
in such a manner, "the Court cut at the heart of the issues of mutual trust underlying the referring court's query: $[\mathrm{T}] \mathrm{o}$ what extent can the executing authority make a decision based on its own judgment of the conduct of the authorities in the issuing State?"114

The Court approached this question in line with its interpretation of finally judged in earlier ne bis in idem case law, thus in accordance with the law of the state where the proceedings took place. ${ }^{115}$ This, however, left open the issue of which judicial authority is to interpret this law. Before clarifying, the Court first underlined the importance of the cooperative stimulus of Article 15(2) EAW, an expression of the trust climate: First consultation between judicial authorities-dialogue-before litigation. The Court observed that in the main proceedings, the German court specifically used the cooperative arrangement, and that "it was clear from the reply given by the issuing judicial authority that the first judgment of the Tribunale di Catania could not be regarded as having definitively barred further prosecution at national level in respect of the acts referred to in the arrest warrant issued by it." 116 Consequently, the German authorities were "obliged to draw all the appropriate conclusions from the assessments made by the issuing judicial authority in its response." ${ }^{117}$ Following these findings, the Court resolutely concluded that "the executing judicial authority has no reason to apply, in connection with such a judgment, the ground for mandatory non-execution provided for in Article 3(2) of the Framework Decision." 118

Therefore, the central question in Mantello is the extent of control that executing authorities are authorized to perform with under the EAW scheme. According to Weyembergh, "this case shows ... very clearly the sensitiveness of [that] question . . . and the uneasiness of the Court when confronted with it." 119 The Court was clear in rejecting any room for a requested authority to interpret matters decided in the issuing state.

Mantello, thus, clearly:

[R] eflects the tension between the application of the principle of mutual recognition in criminal matters on the one hand and the limits of mutual trust between the authorities which are asked to apply the principle on the other, especially when the protection of fundamental rights is at stake. ${ }^{120}$

Instead of trying to find a balance between the two competing interests, the Court prioritizes an effective principle of mutual recognition by ordering national judicial authorities to respect decisions made by its counterparts on the basis of presumed trust.

\section{F. The First Rebuttal of the Trust Presumption: N.S. and M.E., Expanded by C.K.}

Critiques against the Court's strict adherence to mutual trust and disregard of fundamental rights concerns increased following Mantello. It was, however, in the context of the common European asylum system - a field of the AFSJ also governed by mutual recognition and mutual trust ${ }^{121}$ where the Court first made a dent in the trust presumption. The Dublin system of intra-EU transfers of asylum seekers allocates responsibility for each asylum seeker to a single Member

\footnotetext{
${ }^{114}$ Mitsilegas, supra note 23 , at 347.

${ }^{115}$ Mantello, Case C-261/09 at paras. 45-47;see also section B of this Article above.

${ }^{116}$ Mantello, Case C-261/09 at para. 49.

${ }^{117} I d$. at para. 50 .

${ }^{118} I d$. at para. 51.

${ }^{119}$ Anne Weyembergh, Transverse Report on Judicial Control in Cooperation in Criminal Matters: The Evolution from Traditional Judicial Cooperation to Mutual Recognition, in 1 TOWARD A Prosecutor FOR THE EUROPEAN UNION 945, 950 (Katalin Ligeti ed., 2013).

${ }^{120}$ Mitsilegas, supra note 23 , at 348.

${ }^{121}$ See, e.g., Valsamis Mitsilegas, Solidarity and Trust in the Common European Asylum System, 2 COMP. MigRATION STUD. 181 (2014).
} 
State based, among other things, on which Member State's border the asylum seeker illegally crossed first. ${ }^{122}$

In N.S., the Court held that Article 4 of the EU Charter-prohibition of torture and inhuman or degrading treatment-precluded the transfer of an asylum seeker from one Member State to another in accordance with the Dublin Regulation if there are systemic deficiencies in the asylum procedure and reception conditions in the receiving Member State that give rise to a real risk of the asylum seeker being subjected to inhuman or degrading treatment. ${ }^{123}$ The Court "made clear ... that 'non-rebuttable trust' is not allowed when this would jeopardize the protection of the fundamental rights of the individual," 124 and put an end to "blind trust across the EU."125 The Court did not take the matter lightly as it underlined that:

[A]t issue here is the raison d'être of the European Union and the creation of an area of freedom, security and justice ... based on mutual confidence and a presumption of compliance, by other Member States, with European Union law and, in particular, fundamental rights. ${ }^{126}$

Significant in this paragraph is the holding that mutual trust relates to the raison d'etre of the EU. ${ }^{127}$ By doing so, the Court "revealed that mutual trust is not only a normative principle underpinning secondary law instruments but also a distinctive feature of the contemporary EU legal system." ${ }^{28}$ The normative value that it attempts to uphold is to maintain diversity-and a sense of sovereignty - a core feature of mutual recognition while complying with fundamental rights norms, one of the foundational values of the EU. ${ }^{129}$

The Court thus explicitly limited the conclusive presumption of trust, as this "is incompatible with the duty of the Member States to interpret and apply the Regulation in a manner consistent with fundamental rights." ${ }^{30}$ This rather drastic change to the system of inter-state cooperation in the AFSJ was subsequently incorporated into the Dublin Regulation. ${ }^{131}$

The significance of this seminal ruling is wider than the asylum context. According to Mitsilegas, N.S. "constitutes a significant constitutional moment in European Union law," 132 and "a turning point in the evolution of inter-state cooperation in the Area of Freedom, Security and Justice." 133 Lenaerts emphasizes that "what is interesting about the N.S. judgment is that the ECJ did not ground the principle of mutual trust in the particular context of the Dublin Regulation, but qualified it as a constitutional principle." 134 In the capacity of constitutional principle, the importance of mutual trust pertains to the entire AFSJ, and possibly the entire EU.

\footnotetext{
${ }^{122}$ Regulation 604/2013, 2013 O.J. (L 180) 31 (EU).

${ }^{123}$ Joined Cases C-411/10 \&amp; C-493/10, N.S. and M.E., 2011 E.C.R. I-13905, para. 86; see Maarten den Heijer, Joined Cases C-411 \& 493/10, N.S. v. Secretary of State for the Home Department and M.E. and Others v. Refugee Applications Commissioner, Minister for Justice, Equality and Law Reform, Judgment of the Court (Grand Chamber) of 21 December 2011, 49 Common MKT. L. Rev. 1735, 1736 (2012) (providing a case note); the Court later confirmed N.S. in Case C-4/11, Bundesrepublik Deutschland v. Puid, para. 30 (Nov. 14, 2013), http://curia.europa.eu/.

${ }^{124}$ Evelien Brouwer, Mutual Trust and the Dublin Regulation: Protection of Fundamental Rights in the EU and the Burden of Proof, 9 Utrecht L. ReV. 135 (2013).

${ }^{125}$ See Cathryn Costello, Dublin-Case NS/ME: Finally, an End to Blind Trust Across the EU?, 2 Asiel \& MigranTENRECHT 83 (2012).

${ }^{126}$ N.S. and M.E., Joined Cases C-411/10 \& C-493/10 at para. 83.

${ }^{127}$ See Gerard, supra note 28, at 71-79 (analyzing mutual trust as a raison d'être).

${ }^{128}$ See Gerard, supra note 28 , at 73.

${ }^{129}$ See TEU arts. 2, 4(2), 6; TFEU art. 67(1).

${ }^{130}$ N.S. and M.E., Joined Cases C-411/10 \& C-493/10 at paras. 99, 100, 104.

${ }^{131}$ Article 3(2) allows refusal if there is a systematic deficiency.

${ }^{132}$ Mitsilegas, supra note 121 , at 193.

${ }^{133}$ Mitsilegas, supra note 23, at 358.

${ }^{134}$ Koen Lenaerts, The Principle of Mutual Recognition in the Area of Freedom, Security and Justice, THE FOURTH ANNUAL Sir Jeremy Lever Lecture All Souls College, 6 (Jan. 30, 2015).
} 
N.S. partially followed the European Court of Human Rights ("ECtHR") in MSS v. Belgium and Greece, which reached a similar conclusion. ${ }^{135}$ But whereas the CJEU set a rather high threshold-requiring systemic deficiencies-the ECtHR takes a different approach in the subsequent Tarakhel case, only requiring "a thorough and individualised examination" of the impact of a decision on a person. ${ }^{136}$ Applying this lighter test in Tarakhel, the ECtHR finds a breach of individual rights, regardless of a lack of a finding of generalized systematic deficiencies in the receiving state. ${ }^{137}$

At first reading, Tarakhel marks a split between the two Courts. But in N.S., the Court left scope for individualized examination of fundamental rights, and ultimately "squared the circle between mutual trust and human rights." ${ }^{\prime 38}$ In C.K. ${ }^{139}$ the Court held that transfer under Dublin can be refused because of individualized circumstances that would constitute a real risk to inhuman and degrading treatment.

If anything, and to end this section on a positive note from the perspective of fundamental rights, N.S. and C.K. are indications of a growing relation between the CJEU and the ECtHR. ${ }^{140}$ MSS and Tarakhel pushed the boundaries, ultimately leading to N.S. and C.K.. This is a clear example of the successful dialogue between the two courts on human rights matters and how one can strengthen protection in the other. ${ }^{141}$

\section{G. A Human Rights Refusal Ground Under the European Arrest Warrant Post N.S.? Not Yet}

\section{Urgent Calls to Extend N.S. to the Criminal Law Sphere}

Not surprisingly, following N.S., the question as to whether the outcome should apply to the other AFSJ fields_-like the EAW - came up shortly after. Peers unequivocally found that "logically, the judgment should apply by analogy to other areas of Justice and Home Affairs law,"142 and Mitsilegas stated that N.S. "signifies the end of automaticity in inter-state cooperation not only as regards the Dublin Regulation, but also as regards cooperative systems in the fields of criminal law and civil law." 143 Similarly, Bay Larsen noted in relation to a ECtHR case on civil law cooperation regarding child custody in which the trust presumption was rebutted ${ }^{144}$ that:

There seems to be no particular reason why such a jurisprudence should be limited to mutual recognition in one specific part of the [AFSJ] ... and should not affect mutual recognition in another part of that area (such as penal law co-operation). ${ }^{145}$

\footnotetext{
${ }^{135}$ M.S.S. v. Belgium, App. No. 30696/09, (Jan. 21, 2011), http://hudoc.echr.coe.int/; see Violeta Moreno-Lax, Dismantling the Dublin System: M.S.S. v. Belgium and Greece, 14 EUR. J. Migration \& L. 1 (2012) (providing commentary)

${ }^{136}$ Tarakhel v. Switzerland, App. No. 29217/12, paras. 103-04 (Nov. 4, 2014), http://hudoc.echr.coe.int/; see Cathryn Costello \& Minos Mouzourakis, Reflections on Reading Tarakhel: Is "How Bad is Bad Enough" Good Enough?, 10 A\&MR 404 (2014) (providing a case note).

${ }^{137}$ Tarakhel, App. No. 30696/09 at para. 115

${ }^{138}$ Cecilia Rizcallah, The Dublin System: The ECJ Squares the Circle Between Mutual Trust and Human Rights Protection, EU LAW ANALYsis (Feb. 20, 2017), http://eulawanalysis.blogspot.co.uk/2017/02/the-dublin-system-ecj-squares-circle.html.

${ }^{139}$ Case C-578/16 PPU, C. K. v. Republika Slovenija, (Feb. 16, 2017).

${ }^{140}$ See also Brouwer, supra note 124, at 147 (explaining "the two judgments illustrate the close relationship between the EU and the ECHR, and the willingness of the two courts to take note of each other's judgments.").

${ }^{141}$ See, e.g., Fundamental Rights in the EU: A Matter fOr Two Courts (Sonia Morano-Foadi \& Lucy Vickers eds., 2015) (discussing the relation between the CJEU and ECtHR).

${ }^{142}$ See Steve Peers, Court of Justice: The NS and ME Opinions - The Death of "Mutual Trust", Statewatch Analysis, (Sep. 22, 2011) http://www.statewatch.org/analyses/no-148-dublin-mutual-trust.pdf (commenting in response to the Advocate General's Opinion, which the Court followed).

${ }^{143}$ Mitsilegas, supra note 23 , at 358.

${ }^{144}$ Šneersone v. Italy, App. No. 14737/09, (July 12, 2011).

${ }^{145}$ Bay Larsen, supra note 29, at 152.
} 
But in the EAW cases directly following N.S., the emphasis on the effectiveness of mutual recognition and the limited options for refusal remained, ${ }^{146}$ attracting strong criticism. ${ }^{147}$ It took several years before the Court applied N.S. to the penal area in Aranyosi and Căldăraru, which section I discusses more. For example, in Melvin West, addressing consent in cases of onward surrender, the Court held that only the consent required is of the Member State that carried out the last surrender. ${ }^{148}$ The Court reiterated that the EAW operates on the basis of a "high degree of confidence which should exist between the Member States." ${ }^{149}$ While continuing its support of mutual trust, the Court's choice for should exist marks a difference with its earlier statement in Advocaten voor de Wereld, where trust is alleged to already exist. The Court furthermore stresses that "the principle of mutual recognition does not impose an absolute obligation to execute the European arrest warrant," ${ }^{150}$ referring to the various refusal grounds available, ${ }^{151}$ an indication that the Court's earlier rulings on mutual trust should not be understood as implying blind trust.

\section{Radu: The Court Unable - Or Unwilling - to Rule on a Human Rights Refusal Ground}

The first case in which the Court received questions on the existence of a human rights refusal ground in the context of the EAW following N.S. was Radu. ${ }^{152}$ Radu, a suspect of robbery, was arrested in Romania on four German EAWs and did not consent to his surrender. Prior to the execution of the warrants, Radu raised several objections, most notable that the executing state had to ascertain that the issuing state observes the fundamental rights guaranteed by the ECHR and the EU Charter, and in case of a breach, the executing authority would be entitled to refuse to execute the EAW. ${ }^{153}$ In relation to his claim that he would not be given a fair trial, he raised only one point, namely that he was not heard by German authorities prior to issuing the warrants. The Court rejected this argument. A person wanted for an arrest does not need to be heard before issuance because this would render the issuing of arrest warrants highly ineffective, as "an arrest warrant must have a certain element of surprise, in particular in order to stop the person concerned from taking flight." ${ }^{154}$ In addition, the EAW specifically guarantees that the arrested person is entitled to be heard by the executing authority-Article 14. Therefore, the Court ruled that the executing authority cannot refuse to execute an EAW on the ground that the requested person was not heard by the issuing authority. ${ }^{155}$ By concentrating its decision on the right to be heard prior to arrest-a non-existing right- the Court avoided the contentious issue of refusal to execute a warrant when human rights violations occur in the issuing state. ${ }^{156}$

\footnotetext{
${ }^{146}$ See also Martin Böse, Human Rights Violations and Mutual Trust: Recent Case Law on the European Arrest Warrant, in Human Rights in European Criminal Law: New Developments in European Legislation and Case Law after the Lisbon TREaty 135 (Stefano Ruggeri ed, 2015).

${ }^{147}$ See, e.g., Matilde Ventrella, European Integration or Democracy Disintegration in Measures Concerning Police and Judicial Cooperation?, 4 NEW J. EUR. CRIM. L. 290 (2013).

${ }^{148}$ Case C-192/12 PPU, West, (June 28, 2012); see Samuli Miettinen, Onward Transfer under the European Arrest Warrant: Is the EU Moving Towards the Free Movement of Prisoners?, 4 NEWJ. EUR. CRIM. L. 99 (2013).

${ }^{149}$ West, Case C-192/12 PPU at para. 53.

${ }^{150} I d$. at para. 64.

${ }^{151}$ Case C-306/09, I.B., 2010 E.C.R. I-10341, para. 50 (observing that there is no "absolute obligation to execute the arrest warrant.").

${ }^{152}$ Case C-396/11, Radu, (Jan. 29, 2013).

${ }^{153} I d$. at paras. $16-19$.

${ }^{154} \mathrm{Id}$. at para. 40.

${ }^{155} \mathrm{Id}$. at para. 43.

${ }^{156}$ See also JANSSENS, supra note 8, at 208 ("Indeed, whilst in N.S. and M.E. a moderation of the principle of mutual trust was necessary in order to avoid a breach of Article 4 Charter, in Radu there was simply no breach of the Charter, and therefore no need to moderate the principles of mutual recognition and trust".).
} 
Advocate General Sharpston in her opinion, however, came to a different conclusion, and defended a general refusal ground in case of a violation of human rights. ${ }^{157}$ Even though the Court did not follow this part of the opinion, it makes a strong case for such a refusal ground:

[T] he competent judicial authority of the State executing a European arrest warrant can refuse the request for surrender ... where it is shown that the human rights of the person whose surrender is requested have been infringed, or will be infringed, as part of or following the surrender process ... . [be it] only in exceptional circumstances. ${ }^{158}$

The Advocate General proposed a refusal ground in addition to the grounds listed in Articles 3-5 EAW that would be derived from primary EU law-the EU Charter. The simple reason that the Court did not-or could not-follow the Advocate General was that the case did not raise the right question. ${ }^{159}$ This is largely related to the different roles played by both. Whereas the former must answer narrow preliminary questions, the latter has more leeway to ponder on broader legal issues. If the Court eluded to a general refusal ground, it would have done so in obiter dicta, as in this case grounds to make such a ruling were not present. The question was indeed raised whether Member States are required to derogate from mutual recognition when fundamental rights concerns arise, and a prerequisite for answering that question in a concrete case is the actual-and real- existence of such a concern.

Nevertheless, there was disappointment as to the judgment in $R a d u,{ }^{160}$ particularly as it was anticipated that the Court would, for the first time, recognize a human rights refusal ground. As anticipated by Tinsley: "[I]t is hoped that the Court will take the opportunity to deliver helpful precedent on this key component of the EU policy and judicial cooperation system." ${ }^{161}$ In Radu, however, this hope turned out to be in vain.

\section{Melloni: Giving Precedence to EU Fundamental Rights, a Matter of Trust?}

Shortly after Radu, the fundamental rights issue reappeared in Melloni. ${ }^{162}$ An Italian court found Melloni-a fugitive from justice-guilty for bankruptcy fraud and sentenced him to ten years in absentia. ${ }^{163}$ Italian authorities issued an EAW to execute the sentence, and he was arrested by Spanish police. Melloni did not consent to his surrender, but a Spanish court ordered his surrender on the ground that he had been aware from the outset of the trial and had deliberately been absent from trial, as he was represented by two lawyers throughout all stages of the proceedingstrial, appeal, and the rejection of cassation. ${ }^{164}$ Melloni appealed to the Spanish Constitutional

\footnotetext{
${ }^{157}$ Opinion of Advocate General Sharpston, Case C-396/11, Radu (Oct. 18, 2012), http://curia.europa.eu/juris/recherche.jsf? language $=$ en.

${ }^{158} I d$. at para. 97.

${ }^{159}$ See John Spencer, Extradition, the European Arrest Warrant and Human Rights, 72 CAMBrIDGE L.J. 250, 253 (2013) (unequivocally responding to the question whether the authorities are obliged to give the wanted person the opportunity to be heard prior to issuing an EAW: "Of course not.").

${ }^{160}$ See, e.g., Ermioni Xanthopoulou, Radu Judgment: A Lost Opportunity and a Story of How the Mutual Trust Obsession Shelved Human Rights, KSLR EU LAW BLOG (Mar. 27, 2013), https://blogs.kcl.ac.uk/kslreuropeanlawblog/?p=416\#.Wg8K-kpl82w.

${ }^{161}$ Alex Tinsley, The Reference in Case C-396/11 Radu: When Does the Protection of Fundamental Rights Require Non-Execution of a European Arrest Warrant?, 2 EuR. CRIM. L. REV. 338, 350-51 (2012).

${ }^{162}$ Case C-399/11, Melloni v. Ministerio Fiscal, (Feb. 26, 2013); see also Giulia Cavallone, European Arrest Warrant and Fundamental Rights in Decisions Rendered in Absentia: the Extent of Union Law in the Case C-399/11 Melloni v. Ministerio Fiscal, 4 EUR. CRIM. L. ReV 19 (2014).

${ }^{163} \mathrm{~A}$ trial in absentia is a criminal proceeding in which the defendant is not physically present. Whereas some jurisdictions have banned in absentia trials altogether, others not only allow it, but it is actually a commonly used procedure. The large variety of rules on in absentia trials throughout Europe have long been a source of friction in inter-state cooperation, and the problem as such predates mutual recognition. See, e.g., Krombach v. France, App. No. 29731/96, Feb. 13, 2001).

${ }^{164}$ S.A.N., Sept. 12, 2008 (Spain).
} 
Court on the ground that his right to a fair trial-specifically under Article 24(2) of the Spanish Constitution - would be violated because he would have no right to a retrial in Italy. Therefore, he argued, his surrender should be made conditional upon the guarantee of a retrial, or appeal, in Italy. The Spanish Constitutional Court held earlier that the right to participate in person at trial was considered to be part of the absolute content of the right to a fair trial affecting human dignity as protected by the Spanish constitution, and in a similar case it ruled that such an extradition to Romania would indeed violate that right. ${ }^{165}$

In the meantime, the provision in the EAW on trials in absentia-former Article 5(1) - was amended by the new Article 4a, ${ }^{166}$ which aimed to alleviate some of the difficulties that different national practices surrounding in absentia trials posed to the functioning of the EAW. ${ }^{167}$ This new situation triggered the Spanish Constitutional Court—for the first time ever ${ }^{168}$ — to refer the issue to Luxembourg.

The relevant novelty of Article 4a EAW for this case is that execution of an EAW must not be refused if the person concerned "had given a mandate to a legal counsellor, . . . to defend him or her at the trial, and was indeed defended by that counsellor at the trial." 169 Because Melloni's situation met the condition, and Article 4a is an exhaustive provision on the non-execution of EAW's in cases of in absentia convictions, the CJEU held that Spanish authorities had no reason to make surrender conditional upon a retrial in Italy. ${ }^{170}$ There was no violation of his European human rights-for example the EU Charter and ECHR.

This outcome left unanswered the question of whether the higher standard for in absentia trials in the Spanish Constitution can be invoked in a situation that falls within the scope of EU law. ${ }^{171}$ In this respect, Article 53 of the EU Charter is relevant, which provides that: " $\mathrm{N}]$ othing in this Charter shall be interpreted as restricting or adversely affecting human rights and fundamental freedoms as recognized ... by Union and international law ... and by the Member States' constitutions." The Spanish Constitutional Court interpreted this provision as authorizing a Member State to apply its own higher constitutional standard. ${ }^{172}$ The CJEU, however, disagrees: "Such an interpretation of Article 53 of the Charter cannot be accepted," as it would undermine the unity, primacy, and effectiveness of EU law, ${ }^{173}$ as well as mutual trust-an objective of the EAW. ${ }^{174}$ In this relation, the Court reminded us of "the objective set for the European Union to become an area of freedom, security and justice by basing itself on the high degree of confidence which should exist between the Member States."

\footnotetext{
${ }^{165}$ See S.T.C., Mar. 30, 2000 (S.T.C., No. 107) (Spain); S.T.C., Sept. 28, 2009 (S.T.C., No. 199) (Spain) .

${ }^{166}$ Council Framework Decision 2009/299/JHA, 2009 O.J. (L 81/24); the new Article 4a was modelled after the case law of the ECtHR, see Recital 8; see, e.g., Sejdovic v. Italy, App. No. 56581/00, (Mar. 1, 2006).

${ }^{167}$ Melloni, Case C-399/11 at para. 62; see also Martin Böse, Harmonizing Procedural Rights Indirectly: The Framework Decision on Trials in Absentia, 37 N.C. J. INT'L L. \& CoM. REg. 489 (2011).

${ }^{168}$ See Aida Torres Pérez, Constitutional Dialogue on the European Arrest Warrant: The Spanish Constitutional Court Knocking on Luxembourg's Door; Spanish Constitutional Court, Order of 9 June 2011, ATC 86/2011, 8 EUR. CONST. L. REV. 105, 119-24 (2012) (regarding the reasons for this first ever preliminary reference).

${ }^{169} \mathrm{EAW}$ art. $4 \mathrm{a}$.

${ }^{170}$ Melloni, Case C-399/11 at paras. 42-46.

${ }^{171}$ This issue was already raised prior to the Charter's coming into being. See, e.g., Leonard Besselink, Entrapped by the Maximum Standard: On Fundamental Rights, Pluralism and Subsidiarity in the European Union, 35 COMMON MKT. L. REV. 629 (1998).

${ }^{172}$ Melloni, Case C-399/11 at para. 56.

${ }^{173} \mathrm{Id}$. at paras. $57-60$.

${ }^{174} I d$. at para. 63 ("[C]asting doubt on the uniformity of the standard of protection of fundamental rights as defined in that framework decision, would undermine the principles of mutual trust.").

${ }^{175} I d$. at para. 37.
} 
Various authors agree with the Court that Article 53 Charter does not aim to modify the primacy of EU law. ${ }^{176}$ For example, De Witte holds that if:

[T] he Charter's authors had wanted to change such a prominent feature of Community law, which the Court of Justice had constantly affirmed over the years, they would have formulated it in clear terms; but even if they had wished to do so, the authors of the Charter did not have the legal authority to modify primary EU law. ${ }^{177}$

From the viewpoint of protecting the unity and primacy of the EU legal order, the decision in Melloni is rather uncontroversial and simply reiterates a position the Court defended for a long time. ${ }^{178}$ Nevertheless, from a fundamental rights perspective, a number of critical remarks may be made. ${ }^{179}$ First, it is not farfetched to apply national constitutional provisions to EAW proceedings, especially considering the EAW itself refers to these in the preamble. ${ }^{180}$ Second, in the field of judicial cooperation in civil matters, a national public order refusal ground is common, ${ }^{181}$ which seems rather counterintuitive because criminal law is a field with a much greater potential for infringement of individual rights. ${ }^{182}$

The most fundamental concern with the Court's approach in Melloni, though, is with its focus on the primacy of non-directly effective secondary EU law over the protection of fundamental rights-EU primary law. ${ }^{183}$ Protecting the primacy and effectiveness of EU law is a legitimate interest, but it should serve protection of individual rights - a foundational value, Article 2 of the TEU-not vice versa. Defending the effectiveness of EU law, justified by presumed mutual trust, gives preference to upholding a system of effective law enforcement cooperation among Member States over constitutional human rights law and "constitutes a serious challenge for human rights protection."184

Moreover, the concern was raised that the judgment will erode on constitutional pluralityArticle 4(2) TEU—and that national constitutional courts could trigger Solange ${ }^{185}$ in response, ${ }^{186}$ giving rise to conflicts between the CJEU and national constitutional courts. ${ }^{187}$ The Spanish

\footnotetext{
${ }^{176}$ See Jonas Bering Liisberg, Does the EU Charter of Fundamental Rights Threaten the Supremacy of Community Law?, 38 Common MKT. L. Rev. 1171, 1181 (2001) (arguing that Article 53 is merely symbolic, and that it was only included to ensure that Member States would not have to make constitutional amendments; this interpretation was explicitly taken over by Advocate General Bot in his Opinion); see also Cavallone, supra note 162, at 34.

${ }^{177}$ Bruno de Witte, Article 53-Level of Protection, in The EU Charter of Fundamental Rights: A Commentary 1523, 1532-33 (Steve Peers, Tamara Hervey, Jeff Kenner \& Angela Ward eds., 2014).

${ }^{178}$ See also John Vervaele, The European Arrest Warrant and Applicable Standards of Fundamental Rights in the EU, 6 REV. EUR. ADMIN. L. 37, 52-53 (2013).

${ }^{179}$ See, e.g., Leonard Besselink, The Parameters of Constitutional Conflict After Melloni, 39 Eur. L. ReV. 531 (2014); Nikos Lavranos, The ECJ's Judgments in Melloni and Åkerberg Fransson: Une Ménage à Trois Difficulté, 4 GRUNDRECHTE 133 (2013).

${ }^{180}$ See EAW recital 12 ("This Framework Decision does not prevent a Member State from applying its constitutional rules relating to due process, freedom of association, freedom of the press and freedom of expression in other media.").

${ }^{181}$ See, e.g., Regulation 44/2001, art. 34(1), 2001 O.J. (L 12/1) (EC) ("A judgment shall not be recognized 1. If such recognition is manifestly contrary to public policy in the Member State in which recognition is sought.").

${ }^{182}$ Besselink, supra note 179, at 546 (noting that "[p]rivate law 'public policy' is paradoxically a stronger ground for exceptions to mutual recognition than public law 'public policy.").

${ }^{183}$ TEU art. 6(1) (stating that the Charter "shall have the same legal value as the Treaties.").

${ }^{184}$ Valsamis Mitsilegas, Judicial Concepts of Trust in Europe's Multi-Level Security Governance, 3 EUCRIM 90, 91 (2015).

${ }^{185}$ The doctrine developed by the German Constitutional Court that as long as EU fundamental rights are in check with national constitutional safeguards, no further action or review is required. See Bundesverfassungsgericht [BVERFGE] [Federal Constitutional Court], Oct. 22, 1986, BvR Re Wünsche Handelsgesellschaft 73, 339, 376 (1986).

${ }^{186}$ Jan-Herman Reestman \& Leonard Besselink, Editorial: After Åkerberg Fransson and Melloni, 9 Eur. Const. L. Rev. 169 (2013)

${ }^{187}$ Asterios Pliakos \& Georgios Anagnostaras, Fundamental Rights and the New Battle Over Legal and Judicial Supremacy: Lessons from Melloni, 34 Y.B. EUR. L. 97 (2015).
} 
Constitutional Court ultimately followed the Court's interpretation of Article 53 of the Charter in Melloni. ${ }^{188}$ It did not, however, do so easily. ${ }^{189}$

To complete the discussion on the reach of the Charter, the Court-on the same day it handed down its judgment in Melloni-held in Akerberg Fransson that Member States are broadly required to respect the rights contained in the Charter when implementing and applying EU law. ${ }^{190}$ Even though the latter case did not directly concern cooperation in criminal matters, the cases are complementary. Whereas one case guarantees the application of the Charter when EU law is at stake, the other case holds that the Charter provides an upper limit regarding the safeguarding of fundamental rights, at least when it concerns a right harmonized at the EU level. ${ }^{191}$ Fransson — and also the subsequent Jeremy $F^{192}$-indicated that when such harmonization has not taken place, the Member States have a wider margin to provide additional safeguards. ${ }^{193}$

\section{H. Opinion 2/13: A Showcase of the Importance of-the Presumption of-Mutual Trust}

An avenue which the Court used to further strengthen and develop the trust presumption is in the context of the EU's accession to the ECHR. ${ }^{194}$ In the heavily criticized ${ }^{195}$ Opinion $2 / 13,{ }^{196}$ the Court declared the draft Agreement for Accession to be incompatible with primary EU law. ${ }^{197}$ The Court did not limit its analysis to the accession question, but the Opinion's "relevance goes far beyond it." 198 The Court expressed concerns that accession could undermine mutual trust and reiterated that it considers mutual trust an essential component in order to create "an ever closer Union." ${ }^{199}$ The EU's common values-Article 2 of the TEU_"impl[y] and justif[y] the existence of mutual trust between the Member States that those values will be recognized and, therefore, that the law of the EU that implements them will be respected." 200

The assertion that these common values both imply and justify the existence of mutual trust establishes a presumption that is almost impossible to rebut. The common values that imply trust are codified in primary EU law-Article 2 TEU - and as such their implied existence is hard to deny. For example, one cannot easily make the argument that Member States do not share these values, at least in a broad, abstract manner. But if those same values also justify trust-making it

\footnotetext{
${ }^{188}$ S.T.C., Feb. 13, 2014 (S.T.C., No. 26) (Spain).

${ }^{189}$ See Aida Torres Pérez, Melloni in Three Acts: From Dialogue to Monologue, 10 Eur. Const. L. Rev. 308 (2014) ("While the outcome does fulfil the mandates of EU law, the reasoning proves quite unsettling.").

${ }^{190}$ Case C-617/10, Åklagaren v. Åkerberg Fransson, (Feb. 26, 2013); see also Case C-206/13, Siragusa v. Regione Sicilia, paras. 24, 31 (Mar. 6, 2014), (giving a broad interpretation of Article 51 Charter's clause "implementing Union law").

${ }^{191}$ See Rick van der Hulle \& Rob van der Hulle, De arresten Åkerberg Fransson en Melloni gerelativeerd, 3 TIJDSCHRIFT VOOR EUROPEES EN ECONOMISCH RECHT 102 (2014) (examining both cases).

${ }^{192}$ Case C-168/13 PPU, Jeremy F. v. Premier Ministre, para. 75 (May 30, 2013); see Christine Janssens, Zaak C-168/13, Jeremy F., 2 SEW 84 (2014) (providing a case note); Åkerberg Fransson, Case C-617/10 at para. 29.

${ }^{193}$ See also Daniel Sarmiento, Who's Afraid of the Charter? The Court of Justice, National Courts and the New Framework of Fundamental Rights Protection in Europe, 50 Common MKt. L. Rev. 1267 (2013).

${ }^{194}$ See, e.g., Paul Gragl, The Accession of the European Union to the European Convention on Human Rights (2013) (regarding the EU's accession to the ECHR).

${ }^{195}$ Steve Peers (@StevePeers), TwITTER (Dec. 18, 2014, 2:18 AM), https://twitter.com/stevepeers/status/545523536551768064? lang=en (calling the judgment "exceptionally poor").

${ }^{196}$ Opinion 2/13 of 18 December 2014 [hereinafter Opinion 2/13]; see, e.g., Special Section-Opinion 2/3: The E.U. and the European Convention on Human Rights, 16 GERMAN L.J. 106 (2015).

${ }^{197}$ See Steve Peers, The EU's Accession to the ECHR: The Dream Becomes a Nightmare, 16 German L.J. 213, 213 (2015) (criticizing the decision and discussing that binding Opinion found several obstacles and has made accession very difficult; criticizing for seeking to protect basic elements of the EU legal order "by disregarding the fundamental values upon which the Union was founded").

${ }^{198}$ Fisnik Korenica \& Dren Doli, A View on CJEU Opinion 2/13's Unclear Stance on and Dislike of Protocol 16 ECHR, 22 Eur. Pub. L. 269, 269 (2016).

${ }^{199}$ Opinion $2 / 13$ at para. 167.

${ }^{200} I d$. at para. 168.
} 
impossible to argue that there is no foundation for trust as the implied ground is codified in the Treaties - this in effect creates an irrefutable presumption of trust.

Furthermore, the Court, by "drawing on its previous rulings in N.S. and Melloni," 201 puts forward something of a definition:

The principle of mutual trust between the Member States is of fundamental importance in EU law, given that it allows an area without internal borders to be created and maintained. That principle requires, particularly with regard to the area of freedom, security and justice, each of those States, save in exceptional circumstances, to consider all the other Member States to be complying with EU law and particularly with the fundamental rights recognised by EU law. ${ }^{202}$

As in earlier cases, the definition predominantly builds on compliance with fundamental rights but speaks more broadly of compliance with EU law. The Court continued its more familiar line of reasoning, though, by allowing no significant space for evaluation of other Member State's human rights records, as EU law requires this presumption to be firm. ${ }^{203}$ Accordingly-except for exceptional cases-Member States are barred from "check[ing] whether that other Member State has actually, in a specific case, observed the fundamental rights guaranteed by the EU." ${ }^{204}$ One of the main reasons why the Court found the draft Agreement incompatible with the Treaties is its failure to sufficiently acknowledge — or even protect — the trust presumption, which is a constitutional obligation on Member States. ${ }^{205}$ This particular reasoning does not display great belief in the existence of trust: If the trust presumption is well-founded in practice, this should not be a concern. The Meijers Committee also doubted the implications of a Member State checking another's human rights compliance, whether it:

[W]ould seriously threaten the balance between mutual trust and human rights obligations, and hence undermine the autonomy of EU law, ... [instead] such checks are rather likely to reinforce the integrity of Union law. ${ }^{206}$

Turning the trust presumption into an obligation ${ }^{207}$ seems to embody a further step in preserving the mutual trust fiction. Such "an interpretation is far removed from what even an everyday notion of a concept of trust entails; few would contest that if one would be 'obliged' to trust (under penalty of law) this can no longer be considered a genuine trust relation." 208 This "represents a significant challenge to our understanding of the EU constitutional order as a legal order underpinned by the protection of fundamental rights."209

Opinion 2/13 moreover determines_elevates - the status of mutual trust, namely a principle "of fundamental importance in EU law." 210 The Court seemed unsure whether a subjective notion such as trust could carry the weight of a general principle of EU law ${ }^{211}$ that can satisfy

\footnotetext{
${ }^{201}$ Lenaerts, supra note 134 , at 6.

${ }^{202}$ Opinion $2 / 13$ at para. 191.

${ }^{203} I d$. at para. 192.

${ }^{204} I d$.

${ }^{205} I d$. at para. 194.

${ }^{206}$ Meijers Committee, Note on Mutual trust and Opinion 2/13 on Accession of the European Union to the European Convention on Human Rights, CM1604 3 (2016), http://www.commissie meijers.nl/nl/comments/406.

${ }^{207}$ Opinion 2/13 at para. 194, ("EU law imposes an obligation of mutual trust between those Member States.").

${ }^{208}$ Willems, supra note 3 , at 226.

${ }^{209}$ Mitsilegas, supra note 184 , at 92.

${ }^{210}$ Opinion $2 / 13$, at para. 191 .

${ }^{211}$ See generally TAKis Tridimas, The General Principles of EU LAW (2d ed. 2007); see John Vervaele, European Criminal Law and General Principles of Union Law, in EUROPEAN EvidenCE WARRANT: TranSNATIONAL JUdICIAL INQUIRIES IN THE EU 131 (John Vervaele ed., 2005) (regarding criminal law).
} 
requirements of legal certainty. ${ }^{212}$ It therefore stayed short of according the status of a general principle of EU law, but rather cleverly labels it a principle of fundamental importance, without the addition "of EU law." This contributes further to mutual trust's status as a quasi-constitutional axiom, ${ }^{213}$ and leaves much to desire as to what such a principle is. That it is a principle with legal relevance is clear, but by categorizing it as an elevated principle, not a general principle, it must be further developed what status-and content-it has.

\section{A Change of Direction, More Deference to Fundamental Rights and Less to Mutual Trust: Lanigan, Aranyosi and Căldăraru, and Onwards}

\section{Lanigan: Change is in the Air}

In Radu and Melloni, the general question of whether a Member State can be required to scrutinize the fundamental rights compliance of its fellow Member States was left open. Subsequently, the emphasis on the importance of mutual trust and its presumed existence was strengthened by Opinion 2/13. Nevertheless, the issue of the negative impact of mutual trust on fundamental rights remained on the agenda, and a change of direction was in the making. First, in Lanigan, the Court made strong reference to the importance of respect for human rights, and subsequently in the landmark case Aranyosi and Căldăraru, rebuttal of mutual trust materialized.

In Lanigan, ${ }^{214}$ the issue of expiration of the EAW's time limits was raised, which relates to the right to a speedy trial as an aspect of the fundamental right to a fair trial. The Irish High Court asked the CJEU whether the failure to observe those time limits precludes it from executing the EAW and whether Lanigan may be held in custody even though the total duration of the period he has spent in custody exceeds those time limits. Lanigan, who was wanted on murder charges in the UK, resisted the extradition and during his appeal he was detained in Ireland. In its reply, the Court first reiterated the need for strict compliance to the time limits in the EAW. ${ }^{215}$ Nevertheless, in the case at hand, the continued detention of Lanigan did not invalidate the EAW itself, nor was there an obligation to release him. This outcome seems rather contradictory with the Court stressing strict time limits. But according to the Court, the underlying principle is that even if deadlines expire, the EAW remains valid; in other words, saying that "the 'time limit' was not really a time limit at all." 216

To mitigate the absence of a real deadline to execute an EAW - and accordingly the obligation to release a fugitive - which could result in indefinite detention without trial, the Court emphasized the duty of both the issuing and the executing states to observe fundamental rights obligations, in a similar vein as in Jeremy $F .^{217}$ The rules on detention are subject to Article 6 of the EU Charter - the right to liberty and security-and Article 5 of the ECHR. ${ }^{218}$ Still, because in this case no fundamental rights were actually violated, the Court did not have to go into the possible consequence of such a finding. Nevertheless, Lanigan shows signs of a Court being increasingly concerned with fundamental rights within the EAW system.

\footnotetext{
${ }^{212}$ See also Mitsilegas, supra note 184, at 92 ("The Court asserts boldly that mutual trust is not only a principle, but also a principle of fundamental importance in EU law. This assertion, however, seems to disregard the inherently subjective nature of trust and the difficulties in providing an objective definition that meets the requirements of legal certainty.").

${ }^{213}$ Herlin-Karnell, supra note 13 , at 43 ; see also Gerard, supra note 28 , at 69 ("[M] $[\mathrm{Mtual}$ trust . . is widely perceived as axiomatic in nature.").

${ }^{214}$ Case C-237/15 PPU, Minister for Justice and Equality v. Lanigan, (July 16, 2015).

${ }^{215}$ See also Jeremy F., Case C-168/13 PPU at paras. 60-65, 73-74.

${ }^{216}$ Steve Peers, Free at last? Detention, the European Arrest Warrant and Julian Assange, EU L. ANALYsis (Feb. 5, 2016), http://eulawanalysis.blogspot.co.uk/2016/02/free-at-last-detention-european-arrest.html (writing that Peers "wouldn't advise students, lawyers, journalists or many others to take the same approach to deadlines").

${ }^{217}$ Jeremy F., Case C-168/13 PPU at paras. 40-41.

${ }^{218}$ Case C-294/16 PPU, JZ v. Prokuratura Rejonowa Łódź, (July 28, 2016), (aligning subsequently the EAW’s definition of detention with relevant ECtHR caselaw).
} 


\section{Aranyosi and Căldăraru: A Landmark Ruling for Fundamental Rights and Mutual Trust}

In the "eagerly awaited decision"219 of Aranyosi and Căldăraru, 220 the Court ruled that the execution of an EAW must be postponed if there is a real risk of inhuman or degrading treatment because of detention conditions in the requesting Member State. ${ }^{221}$ Favoring human rights over the efficient operation of mutual recognition for the first time is a watershed moment in the jurisprudence on criminal justice. It cannot have come as a surprise that the first case was in relation to prison conditions, as it is well known that these often fall short of minimum standards across the EU, in particular in times of economic austerity. ${ }^{222}$

As to the facts of the case, ${ }^{223}$ Germany received two requests for surrender: Regarding Aranyosi-a Hungarian national residing in Germany-Hungary issued two EAWs for prosecution purposes for two counts of burglary. Regarding Căldăraru—a Romanian national whose case was joined-an EAW was issued seeking the execution of a prison sentence for driving without a license. Both men were apprehended in Germany and did not consent to their surrender.

The ECtHR found earlier that both Hungary and Romania were in violation of Article 3 of the ECHR — prohibition of torture and inhuman or degrading treatment-because of prison overcrowding. ${ }^{224}$ The Higher Regional Court of Bremen therefore referred to Luxembourg an inquiry of whether, in case there is convincing evidence that detention conditions in the issuing Member State are incompatible with fundamental rights, execution of an EAW should be refused, or that in such cases, the executing authority must make the surrender conditional upon assurances that detention conditions are sufficiently safeguarded. ${ }^{225}$

Advocate General Bot, in his opinion, rejected such an interpretation of Article 1(3) of the EAW, as it would be contrary to the EAW scheme and its exhaustive list of refusal grounds. ${ }^{226}$ He held that allowing refusal on fundamental rights grounds would substantially undermine mutual trust between Member States. 227

The Court, however, departed from the Advocate General. ${ }^{228}$ The Grand Chamber, as per usual, first reiterated that "mutual confidence between the Member States that their national legal systems are capable of providing equivalent and effective protection of the fundamental rights

\footnotetext{
${ }^{219}$ Rebecca Niblock, Mutual Recognition, Mutual Trust? Detention Conditions and Deferring an EAW, 7 NEW J. EUR. CRIM. L. 250, 250 (2016).

${ }^{220}$ Joined Cases C-404/15 \& C-659/15 PPU, Aranyosi and Căldăraru, (Apr. 5, 2016).

${ }^{221}$ See also Emmanuelle Bribosia \& Anne Weyembergh, Arrêt “Aranyosi et Caldararu”: Imposition de Certaines Limites à la Confiance Mutuelle dans la Coopération Judiciaire Pénale, 6 J. DroIT EuropéEN 25 (2016); Szilárd Gáspár-Szilágyi, Joined Cases Aranyosi and Căldăraru: Converging Human Rights Standards, Mutual Trust and a New Ground for Postponing a European Arrest Warrant, 24 EUR. J. CRIME, CRIM. L. \& CRIM. JUST. 197 (2016).

${ }^{222}$ See, e.g., Eur. Comm. Rep, European Committee for the Prevention of Torture and Inhuman or Degrading Treatment or Punishment (2018); see also Debbie Sayers, The EU's Common Rules on Detention: How Serious are Member States About Protecting Fundamental Rights?, EU LAW ANALYsIs (Feb. 17, 2014), http://eulawanalysis.blogspot.co.uk/2014/02/the-euscommon-rules-on-detention-how.html.

${ }^{223}$ Aranyosi and Căldăraru, Joined Cases C-404/15 \& C-659/15 PPU at paras. 28-63.

${ }^{224}$ See, e.g., Vociu v. Romania, App. No. 22015/10, (June 10, 2014); Varga v. Hungary, App. Nos. 14097/12, 45135/12, 73712/12, 34001/13, 44055/13, \& 64586/13 (June 10, 2015).

${ }^{225}$ Aranyosi and Căldăraru, Joined Cases C-404/15 \& C-659/15 PPU at paras. 46, 63.

${ }^{226}$ Opinion of Advocate General Bot at paras. 78-93, Joined Cases C404/15 \& C659/15, Aranyosi and Căldăraru (Mar. 3, 2016), http://curia.europa.eu/juris/recherche.jsf?language=en; see Gáspár-Szilágyi, supra note 221, at 201-06 (analyzing the Opinion).

${ }^{227}$ Opinion of Advocate General Bot, supra note 226, at paras. 106-22.

${ }^{228} \mathrm{It}$ is noteworthy that the positions of the Advocate General and the Court are exactly the opposite from Radu, where Advocate General Sharpston opined in favor of a human rights refusal ground, and the Court did not follow.
} 
recognized at the EU level, particularly in the Charter" is the foundation of mutual recognition. ${ }^{229}$ Second, it proceeded to set out that it follows from these findings that:

[If the] judicial authority of the executing Member State is in possession of evidence of a real risk of inhuman or degrading treatment of individuals detained in the issuing Member State, .. [it] is bound to assess the existence of that risk when it is called upon to decide on the surrender to the authorities of the issuing Member State of the individual sought by a European arrest warrant. ${ }^{230}$

The Court developed a two-tier test to this end. First, it required that "the executing judicial authority must, initially, rely on information that is objective, reliable, specific, and properly updated on the detention conditions prevailing in the issuing Member State," and that any deficiencies found "may be systemic or generalised, or which may affect certain groups of people, or which may affect certain places of detention." 231 Furthermore, Article 3 of the ECHR and relevant case law impose a positive obligation "to ensure that any prisoner is detained in conditions which guarantee respect for human dignity." 232 But this in itself is not sufficient to refuse execution of the EAW. ${ }^{233}$ Second, this leads to the next step, namely the executing authority has to make "a further assessment, specific and precise, of whether there are substantial grounds to believe that the individual concerned will be exposed to that risk because of the conditions for his detention envisaged in the issuing Member State." ${ }^{234}$ In order to diligently make this assessment, the executing authority must request, as a matter of urgency and in accordance with Article 15(2) of the EAW, all additional information necessary to establish the conditions in which the person will be detained. ${ }^{235}$ If the executing authority is then convinced of the existence of a real risk of inhuman or degrading treatment, the execution of the warrant must be postponed, but not abandoned. ${ }^{236}$ The executing authority must decide whether the person wanted will remain in detention-in accordance with Article 6 of the EU Charter and the principles set out in Lanigan. ${ }^{237}$ In case the requested information does not warrant the conclusion that a real risk exists that the individual concerned will be subject to inhuman and degrading treatment, the executing authority must adopt its decision on the execution of the EAW. ${ }^{238}$

The Court thus, for the first time, allowed deferral of an EAW on fundamental rights grounds, and thereby also, for the first time, favored safeguarding individual rights over the effectiveness of mutual recognition and mutual trust in the criminal law sphere. It is hard to underestimate the significance of this judgment for the future development of mutual trust within the AFSJ. It nevertheless raises a number of issues. ${ }^{239}$

The first issue relates to the exact effect of postponement. The Court carefully avoided creating a new refusal ground and opted for mandatory postponement instead. Following a postponement, execution of the warrant "cannot be abandoned." ${ }^{240}$ At the same time, the last paragraph of the judgment states that "[i]f the existence of that risk cannot be discounted within a

\footnotetext{
${ }^{229}$ Aranyosi and Căldăraru, Joined Cases C-404/15 \& C-659/15 PPU at paras. 77-78.

${ }^{230} I d$. at para. 88 .

${ }^{231} I d$. at para. 89 .

${ }^{232} I d$. at paras. $89-90$.

${ }^{233} \mathrm{Id}$. at para. 91.

${ }^{234} I d$. at paras. $92-94$.

${ }^{235} \mathrm{Id}$. at paras. $95-97$.

${ }^{236} I d$. at paras. 98, 99 ("[W] here the executing authority decides on such a postponement, the executing Member State is to inform Eurojust, in accordance with Article 17(7) of the Framework Decision, giving the reasons for the delay.").

${ }^{237} I d$. at paras. 100-02 (stating that such a decision must be made in accordance with the principle of proportionality).

${ }^{238} I d$. at para. 103.

${ }^{239}$ See also Bribosia \& Weyembergh, supra note 221, at 27.

${ }^{240}$ Aranyosi and Căldăraru, Joined Cases C-404/15 \& C-659/15 PPU at para. 98.
} 
reasonable time, the executing judicial authority must decide whether the surrender procedure should be brought to an end."241 It is hard to see how systemic deficiencies in detention conditions will be improved overnight, and it is not likely that this can be remedied within the time limits set out by the EAW. Moreover, postponing a decision does not directly improve prison conditions, creating the risk that those guilty of crimes will move to such Member States in order to enjoy impunity. Therefore, as accurately observed by Gáspár-Szilágyi, the postponement might "easily amount to a de facto ground of refusal to surrender the requested person." 242

One could get the impression that the Court intentionally inserted a degree of ambiguity into its decision. As trust is a process, the first avenue should be Member States resolving such issues with minimal guidance from the Court, and in the process, establishing better relations and trust-i.e. build trust.

The second issue is whether this newly created ground for postponement applies only in relation to detention conditions, or if other human rights infringements also warrant postponement. The right at stake here-Article 3 of the ECHR and Article 4 of the EU Charter-is absolute and "is closely linked to respect for human dignity." 243 Like in previous cases (e.g. Radu), the Court showed a preference for answering the questions referred to it narrowly. The Court explicitly referred to the right not to be subjected to inhuman or degrading treatment and not to any other rights. It is therefore likely that-for now-the ground for postponement only applies in relation to that specific right. Future cases will show whether this will be extended to other fundamental rights, most notably to rights that do not have an absolute character, such as, for example, the right to a fair trial.

A final concern is with the rather high evidentiary threshold required. Because a systemic or generalized deficiency alone does not warrant a refusal, a two-tier system could come into being. As long as issuing authorities show that the individual subject to an EAW will not be detained in an overcrowded facility, general or systematic deficiencies will not have to be addressed. More practically, Member States could designate good facilities for EAW cases, leaving the problems for the bulk of prisoners in place. This would be highly undesirable, as fundamental rights should apply equally and universally throughout the EU.

The Court clearly sought a compromise in Aranyosi and Căldăraru. ${ }^{244}$ On the one hand, by not allowing refusal because of systemic deficiencies alone-as is sufficient before the ECtHR -and by opting for postponement and dialogue, not outright refusal, it attempted to safeguarded the effectiveness of mutual recognition. On the other hand, it answered to calls for fundamental rights limitations to mutual recognition and brought its interpretation of mutual trust more in line with the reality on the ground-a more substantive principle of trust in accordance with real levels of trust — and real fundamental rights deficiencies — rather than a formalistic approach. ${ }^{245}$

Finally, the judgment creates more harmony between the various AFSJ policy fields. The questions raised after N.S. as to whether its reach can be stretched to other areas of the AFSJ were answered positively. Aranyosi and Căldăraru effectively applied N.S. mutatis mutandis to the field of penal law. By doing, so mutual trust gained credibility as a constitutional principle, as different levels of fundamental rights protection within a true AFSJ-aspiring to constitute a single legal space-are hard to justify.

\footnotetext{
${ }^{241} I d$. at para. 104.

${ }^{242}$ Gáspár-Szilágyi, supra note 221 , at 216.

${ }^{243}$ Aranyosi and Căldăraru, Joined Cases C-404/15 \& C-659/15 PPU at para. 85.

${ }^{244}$ See also Bribosia and Weyembergh, supra note 221 , at 27.

${ }^{245}$ See also Gáspár-Szilágyi, supra note 221, at 211 ("[T]he CJEU decided to reconcile the protection of fundamental rights with the principles of mutual trust and recognition.”).
} 


\section{A Continuation of the 'New Approach': Bob-Dogi and Onwards}

Lanigan and Aranyosi and Căldăraru proved to be the beginning of closer scrutiny of issuing Member States' laws and practices in the EAW context. ${ }^{246}$ Or, alternatively, of balancing the effectiveness of mutual recognition justified by trust with due process. In Bob-Dogi, ${ }^{247}$ the Court held that EAWs cannot be issued as individual measures, but need to be underpinned by a national arrest warrant, most importantly because issuing a national arrest warrant guarantees the protection of the suspect's fundamental rights. The otherwise prominent presence of the objective of efficiency of the EAW system was surprisingly absent in this case and only briefly mentioned.

Dworzecki $i^{248}$ concerned once again an in absentia trial and the Court stressed that Member States had to make all possible efforts to find a fugitive prior to trial. If not, non-execution is allowed. This ground for refusal already existed in the EAW, but its reach was extended in favor of safeguarding individual rights.

In a subsequent series of three cases - all handed down on the same day - on the correct interpretation of judicial authority for the purposes of issuing EAWs, the Court held that Member States do not have unlimited discretion in deciding exactly who gets to carry this title. Judicial authorities may extend beyond judges, such as Hungarian prosecutors, ${ }^{249}$ but do not include the Swedish police, ${ }^{250}$ nor Lithuanian ministry of justice officials. ${ }^{251}$ Therefore, in the latter two cases, the EAWs were never validly issued to begin with, in effect adding a ground for non-execution.

In Tupikas, ${ }^{252}$ inquiring once more into in absentia trials, the Court ruled that "the principles of mutual trust and recognition on which that Framework Decision [EAW] is based must not in any way undermine the fundamental rights guaranteed to the persons concerned." 253 This is another strong signal that the days when conflicts between mutual trust and fundamental rights were, by default, resolved in favor of the former are gone. ${ }^{254}$

Finally, the Court made the special character of mutual trust insightful by distinguishing the EAW from extradition to third states. ${ }^{255}$ Regarding the former, the CJEU requires (e.g. in Aranyosi and Căldăraru) a rather high threshold to rebut the trust presumption. Whereas, regarding extradition to Russia in Petruhhin, ${ }^{256}$ the Court held that establishing the existence of an individualised risk, in addition to a more general risk, is not needed. ${ }^{257}$

There are still many more fundamental rights related issues in the EAW context, ${ }^{258}$ but the recent series of "rulings suggest a significant change of direction . . . and may have opened up

\footnotetext{
${ }^{246}$ See Ermioni Xanthopoulou, Mutual Trust and Rights in EU Criminal Law and Asylum Law: Three Phases of Evolution and the Uncharted Territory Beyond Blind Trust, 55 CoMmon MKT. L. REv. 489 (2018) (arguing that these are steps towards the third phase of mutual trust, embracing individual rights assessment, as in asylum law).

${ }^{247}$ Case C241/15, Bob-Dogi, (June 1, 2016).

${ }^{248}$ Case C108/16 PPU, Openbaar Ministerie v. Dworzecki, (May 24, 2016).

${ }^{249}$ Case C453/16 PPU, Openbaar Ministerie v. Özçelik, (Nov. 10, 2016).

${ }^{250}$ Case C452/16 PPU, Openbaar Ministerie v. Poltorak, (Nov. 10, 2016).

${ }^{251}$ Case C477/16 PPU, Openbaar Ministerie v. Kovalkovas, (Nov. 10, 2016).

${ }^{252}$ Case C270/17 PPU, Openbaar Ministerie v. Tupikas, (Aug. 10, 2017).

${ }^{253} \mathrm{Id}$. at para. 59.

${ }^{254}$ See also Case C271/17 PPU, Openbaar Ministerie v. Zdziaszek, para. 66 (Aug. 10, 2017)

${ }^{255}$ See Cecilia Rizcallah, European and International Criminal Cooperation: A Matter of Trust? Case Note 1/2017, COLLEGE Eur. Case Notes (2017).

${ }^{256}$ Case C-182/15, Petruhhin v. Latvijas Republikas Ģenerālprokuratūra, (Sept. 6, 2016); see Martin Böse, Mutual Recognition, Extradition to Third Countries and Union Citizenship: Petruhhin, 54 Common MkT. L. Rev. 1781 (2017).

${ }^{257}$ André Klip, Europeans First!: Petruhhin, an Unexpected Revolution in Extradition Law, 25 EUR. J. CRIME, CRIM. L. \& CRIM. JUST. 195, 204 (2017) ("There is a certain degree of arrogance in the decision. European Union Member States are always trustworthy and will respect free movement and all human rights. Third states do not deserve European trust and violate free movement and human rights.").

${ }^{258}$ See, e.g., Sergio Carrera, Elspeth Guild and N. Hernanz, Europe's Most Wanted? Recalibrating Trust in the European Arrest Warrant System, 55 CEPS PAPER IN LIBERTY \& SECURITY IN EUR. 19-21 (2013), https://www.ceps.eu/publications/ europe $\% \mathrm{E} 2 \% 80 \% 99 \mathrm{~s}$-most-wanted-recalibrating-trust-european-arrest-warrant-system (“[T]he proportionality issue presents one of the major challenges to mutual trust.").
} 
the door to addressing others." ${ }^{259}$ Aranyosi and Căldăraru proved a much needed reconfiguration of the interplay between the principles of mutual recognition and mutual trust. ${ }^{260}$ This change of direction shows the Court is coming to terms with the reality that a trust presumption that does not allow for any scrutiny of one's cooperating partner might ask for too much in an area as sensitive as criminal law.

\section{J. The Court's Evolving View of the Trust Presumption}

The role of the CJEU in the mutual trust narrative is paramount. To come back to the question raised at the beginning of this Article, whether the Court has played the role of a mutual trust stronghold, the short answer seems yes. The CJEU is a steady defender of the trust presumption and attributed a normative meaning to it in three steps: First in the ne bis in idem cases, where trust was presumed to exist despite a large degree of — penal—diversity, second by putting aside concerns raised by national constitutional courts in Advocaten voor de Wereld, where a high level of confidence in the context of the EAW was established, and third in Opinion 2/13, where the presumption of trust was further elevated. The Court is a guarantor of the efficiency of mutual recognition, and mutual trust "served as something like a super-principle to enforce mutual recognition."261

At the same time, the contention that the Court developed the principle of mutual trust "to keep Member States chained under its command" 262 seems a little harsh. It should be remembered that the Council and the Commission gave the Court the mandate to enforce mutual recognition based on a high level of trust. The Court has obviously taken that role very serious, but as the adjudicator of EU law its core function is exactly to protect the primacy and effectiveness of EU law.

A separate and more recent narrative forms through the emerging room for rebuttal of the trust presumption, first in N.S. and second in Aranyosi and Căldăraru, where the Court just stayed clear of recognizing a human rights refusal ground in the context of the EAW. This line of cases, most recently continued in, for example, Tupikas, is more on par with reality and answers to the need of qualifying the principles of mutual recognition and mutual trust, in light of safeguarding due process rights. ${ }^{263}$

A key aspect of these cases is that they concern Charter rights, more in particular Article 4 . The Court found a tool in the Charter that enables it to limit the presumption of mutual trust while preserving the primacy and unity of EU law. This preservation is an objective which it can achieve by allowing exceptions to mutual trust in the form of Charter rights, or alternatively, limitations based on the EU's very own fundamental rights Charter. Therefore, the EU does not need to resort to legal sources outside of its own legal order.

Moreover, this change of direction matches broader developments within EU criminal law. The evolving position of the Commission on the matter became more receptive to the idea of rebutting the trust presumption. ${ }^{264}$ But also, there were developments in secondary EU law, such as the

\footnotetext{
${ }^{259}$ Steve Peers, Human Rights and the European Arrest Warrant: Has the ECJ Turned from Poacher to Gamekeeper?”, EU LAW ANALYSIS (Nov. 12, 2016), http://eulawanalysis.blogspot.be/2016/11/human-rights-and-european-arrest.html.

${ }^{260}$ See also Fisnik Korenica \& Dren Doli, No More Unconditional “Mutual Trust" Between the Member States: An Analysis of the Landmark Decision of the CJEU in Aranyosi and Caldararu, 5 EUr. HuM. RTS. L. Rev. 542 (2016).

${ }^{261}$ Wischmeyer, supra note 11 , at 360 .

${ }^{262}$ Korenica \& Doli, supra note 260, at 542.

${ }^{263}$ Christina Peristeridou \& Jannemieke Ouwerkerk, A Bridge over Troubled Water-a Criminal Lawyers' Response to Taricco II, VerfBlog (Dec. 12 2017), http://verfassungsblog.de/a-bridge-over-troubled-water-a-criminal-lawyers-responseto-taricco-ii/ (noting that the Court continued the Aranyosi reasoning in the recent Tarrico II judgment: "[F]undamental rights can form actual tangible limits to the effectiveness of EU law, which is not treated anymore as a prevailing mantra").

${ }^{264}$ See at 5-6 COM (2005) 63 final, (calling - in its first implementation report-the practice of adding refusal grounds not provided for by the EAW disturbing, but nevertheless legitimate, as long as "these grounds [are only] invoked in exceptional circumstances within the Union," and that "in a system based on mutual trust, such a situation should remain exceptional"), https://eur-lex.europa.eu/legal-content/EN/TXT/PDF/?uri=CELEX:52005DC0063\&from=EN; see at 7 COM (2011) 175 final (specifying in a later report that in the case of poor detention conditions "it is clear that the Council Framework Decision on the EAW does not mandate surrender”), https://eur-lex.europa.eu/LexUriServ/LexUriServ.do?uri=COM:2011:0175:FIN:EN:PDF.
} 
European Investigation Order ("EIO"), which includes a fundamental rights refusal ground, ${ }^{265}$ and the EU's Roadmap, ${ }^{266}$ which sets out a program of procedural rights measures. ${ }^{267}$ Additionally, there has been strong critique from academic commentators and civil society. From that perspective, the Court codified legislative, policy, academic, and civil society developments towards a genuine and balanced AFSJ, ${ }^{268}$ not only focused on crime control and security, but also on due process and justice. ${ }^{269}$

While allowing rebuttal of the trust presumption, the Court has, at the same time, been clear that the "principle of mutual trust between the Member States is of fundamental importance in EU law." ${ }^{270}$ In that connection, mutual trust has been interpreted as "a constitutional principle that pervades the entire AFSJ." ${ }^{271}$ It is unclear, though, whether the Court treated it with the clarity one would wish of such an important principle. It has "not [been] easy to grasp the theory behind the Court's understanding of the principle of mutual trust." ${ }^{272}$ Obliging Member States to adhere to a fiction which is easily rebutted-mainly by pointing to the poor record of human rights compliance throughout the EU-and then calling it trust opens the door to criticism, and possibly to mistrust. By removing any significant degree of control for the cooperating judicial authorities, the Court might have actually eroded levels of trust, contrary to its stated intention of upholding trust. ${ }^{273}$

It is uncertain what the empirical basis is for the Court's strong belief in the existence of trust, but it seems that it inferred from the simple adoption of mutual recognition instruments in secondary EU law that mutual trust exists. ${ }^{274}$ The finding that trust must exist illustrates the Court's attitude, ${ }^{275}$ but feels somewhat forced and runs contrary to the concept of trust-an obligation to trust cannot be considered genuine trust. De Schutter described the Court's approach as axiomatic, as it on the one hand considers trust a "condition de possibilité de la reconnaissance mutuelle," [condition] while on the other it holds "comme présupposée par la reconnaissance mutuelle" [presumption]. ${ }^{276} \mathrm{Or}$ in the words of Costello: "[T]his comes close to asserting that because we believe it, it must be true." 277 If trust would indeed be a precondition to mutual recognition, justified by the mere existence of mutual recognition instruments, the requirement

\footnotetext{
${ }^{265} \mathrm{An}$ EIO is a decision by a judicial authority to have investigative measures carried out in the executing state to obtain evidence, Directive 2014/41/EU, 2014 O.J. (L 130/1); see, e.g., Catherine Heard \& Daniel Mansell, The European Investigation Order: Changing the Face of Evidence-Gathering in EU Cross-Border Cases, 2 NEW J. EUR. CRIM. L. 363 (2011) (regarding the EIO).

${ }^{266}$ Resolution of the Council of 30 November 2009, 2009 OJ (C-295) 1.

${ }^{267}$ See, e.g., Taru Spronken \& Dorris de Vocht, EU Policy to Guarantee Procedural Rights in Criminal Proceedings: "Step by Step”, 37 N.C. J. INT'L L. \& COM. REg 436 (2011).

${ }^{268}$ See Szilárd Gáspár-Szilágyi, Mutual Trust Before the Court of Justice - A View From CJEU Judge Sacha Prechal, ACELG BLOG (Nov. 11 2015), https://acelg.blogactiv.eu/2015/11/11/mutual-trust-before-the-court-of-justice-a-view-from-cjeu-judgesacha-prechal/ (detailing how Judge Prechal has also spoken of providing limits to mutual trust while not upsetting the integrity of the AFSJ).

${ }^{269}$ See, e.g., Ester Herlin-Karnell, The Domination of Security and the Promise of Justice: On Justification and Proportionality in Europe's "Area of Freedom, Security and Justice", 8 Transnational LEgal TheORY 79 (2017).

${ }^{270}$ Opinion $2 / 13$, at para. 191.

${ }^{271}$ See Lenaerts, supra note 134, at 6; the Court was clear that mutual trust is a constitutional principle in all areas comprising the AFSJ In civil matters in Rinau, in asylum law in N.S., and in criminal matters in Melloni.

${ }^{272}$ Wischmeyer, supra note 11 , at 357.

${ }^{273}$ Wischmeyer, supra note 11 , at 367 n.147.

${ }^{274}$ See also Daniel Flore, La Notion de Confiance Mutuelle: $L^{\prime}<<$ alpha $>>$ ou $l^{\prime}<<$ omega $>>$ d'une Justice Pénale Européenne?, in La Confiance Mutuelle Dans l'Espace Pénal Européen/Mutual Trust in the European Criminal Area 17, 19 (Gilles De Kerchove \& Anne Weyembergh eds., 2005).

${ }^{275}$ West, Case C-192/12 PPU at para. 62.

${ }^{276}$ Olivier de Schutter, La Contribution du Contrôle Juridictionnel à la Confiance Mutuelle, in La CONFIANCE MUTUELLE Dans l'Espace Pénal Européen/Mutual Trust in the European Criminal Area 79, 98, 101(Gilles De Kerchove \& Anne Weyembergh eds., 2005).

${ }^{277}$ Costello, supra note 125 , at 90 .
} 
of trust would not have any substance. Such a formalistic and circular reading of the principle allows the Court to rubberstamp even the most controversial mutual recognition measuresan example being the absence of a human rights refusal ground in the EAW.

In Opinion 2/13, the Court took its top-down approach of mutual trust too far by almost obliging Member States to trust. This development is not only worrisome in terms of fundamental rights protection, but it also runs counter to developments in secondary EU criminal law-for example, the EIO - that allow executing authorities to assess whether fellow Member States comply with fundamental rights in executing a judicial decision. Indeed, creating a level playing field of due process guarantees - a development set in motion by the Roadmap-takes time. Therefore, mutual trust necessarily functions as a workable presumption, but not an irrefutable one. If Member States are obliged to consider all other Member States to be fully human rights compliant, there is no longer a need for a concept of trust underlying mutual recognition, because such a concept would be of importance only if trust can come and go, like in social relations. In that capacity, trust should serve as a yardstick, an actual indicator of the temperature on the ground, to move states to respect human rights. Cooperation on a trust basis would be better served by allowing checks for fundamental rights compliance-yes, under limited conditions — rather than permitting or obliging governments to turn a blind eye to violations thereof. ${ }^{278}$ The Court has shown to be willing to go down this new road in Aranyosi and Căldăraru. Future cases will show whether the Court will continue this new road, and provide further-much needed-clarity.

\section{K. Conclusion}

The Court at first appeared to view trust merely functionally-namely enhancing mutual recognition-based cooperation-going from the establishment of the trust presumption in Gözütok and Brügge to an obligation to trust in Opinion 2/13. Subsequently, the Court became aware of the erosion of the grounds underlying mutual recognition, and in the process may have lost its trust in trust. In Aranyosi and Căldăraru, without going as far as recognizing a broad human rights refusal ground, it gave a clear indication that there are limits as to the negative impact that mutual recognition can have on fundamental rights in EU cooperation in criminal justice matters. Subsequent cases have confirmed this. Therefore, it seems safe to conclude that in the context of the AFSJ's criminal law component, the trust presumption should no longer be regarded as rigid as initially set out. This constitutes a more future-proof approach with the potential to construct trust, rather than to destruct it.

\footnotetext{
${ }^{278}$ See also Olivier de Schutter, The Promotion of Fundamental Rights by the Union as a Contribution to the European Legal Space (I): Mutual Recognition and Mutual Trust in the Establishment of the Area of Freedom, Security and Justice, REFGOV FR 2 WORKING PAPER (2006).
} 